\title{
Rapid Assessment of Price Instability and Paucity of Medicines and Protection for COVID-19 Across Asia: Findings and Public Health Implications for the Future
}

\section{OPEN ACCESS}

Edited by:

Hideki Hashimoto,

The University of Tokyo, Japan

Reviewed by:

Guvenc Kockaya,

ECONiX Research, Analysis and Consultancy Plc., Istanbul, Turkey Mihajlo (Michael) Jakovljevic,

Hosei University, Japan

*Correspondence:

Mainul Haque

runurono@gmail.com

TORCID:

Brian Godman

orcid.org/0000-0001-6539-6972

Mainul Haque

orcid.org/0000-0002-6124-7993

Salequl Islam

orcid.org/0000-0001-6131-4132

Samiul lqbal

orcid.org/0000-0003-1625-5924

Umme Laila Urmi

orcid.org/0000-0003-1327-1638

Zubair Mahmood Kamal

orcid.org/0000-0001-9659-2925

Shahriar Ahmed Shuvo orcid.org/0000-0001-6988-4033

Aminur Rahman orcid.org/0000-0002-2665-9095

Mustafa Kamal

orcid.org/0000-0003-1234-2019

Monami Haque

orcid.org/0000-0002-7970-6094

Iffat Jahan

orcid.org/0000-0003-0551-3609

Md. Zakirul Islam orcid.org/0000-0003-3153-1333

Mohammad Monir Hossain orcid.org/0000-0003-2036-5894

Munzur-E-Murshid orcid.org/0000-0001-5503-7757
Brian Godman ${ }^{1,2,3,4+}$, Mainul Haque ${ }^{5 * t}$, Salequl Islam ${ }^{6+}$, Samiul Iqbal ${ }^{7 t}$, Umme Laila Urmi $^{6 \dagger}$, Zubair Mahmood Kamal ${ }^{8 t}$, Shahriar Ahmed Shuvo ${ }^{9 \dagger}$, Aminur Rahman ${ }^{10 t}$, Mustafa Kamal ${ }^{11 \dagger}$, Monami Haque ${ }^{12 \dagger}$, Iffat Jahan ${ }^{13 \dagger}$, Md. Zakirul Islam ${ }^{14 t}$, Mohammad Monir Hossain ${ }^{15 t}$, Munzur-E-Murshid ${ }^{16 t}$, Santosh Kumar ${ }^{17 t}$, Jaykaran Charan ${ }^{18 t}$, Rohan Bhatt ${ }^{19 \dagger}$, Siddhartha Dutta ${ }^{18 t}$, Jha Pallavi Abhayanand ${ }^{18 t}$, Yesh Sharma ${ }^{20 \dagger}$, Zikria Saleem ${ }^{21}$, Thuy Nguyen Thi Phuong ${ }^{22 t}$, Hye-Young Kwon ${ }^{1,23 t}$, Amanj Kurdi ${ }^{1,24 t}$, Janney Wale ${ }^{25}$ and Israel Sefah ${ }^{26,27 \dagger}$

${ }^{1}$ Strathclyde Institute of Pharmacy and Biomedical Sciences, University of Strathclyde, Glasgow, United Kingdom, ${ }^{2}$ Division of Clinical Pharmacology, Karolinska Institute, Karolinska University Hospital Huddinge, Stockholm, Sweden, ${ }^{3}$ School of Pharmacy, Sefako Makgatho Health Sciences University, Pretoria, South Africa, ${ }^{4}$ School of Pharmaceutical Sciences, Universiti Sains Malaysia, Penang, Malaysia, ${ }^{5}$ Unit of Pharmacology, Faculty of Medicine and Defence Health, Universiti Pertahanan Nasional Malaysia (National Defence University of Malaysia), Kuala Lumpur, Malaysia, ${ }^{6}$ Department of Microbiology, Jahangirnagar University, Dhaka, Bangladesh, ${ }^{7}$ Department of Orthodontics, Faculty of Dentistry, Bangabandhu Sheikh Mujib Medical University, Dhaka, Bangladesh, ${ }^{8}$ Integrated Sleep Disorders Center, McGuire VAMCNCU Health, Richmond, VA, United States, ${ }^{9}$ RMC Hospital \& Diagnostic Complex Ltd., Dhaka, Bangladesh, ${ }^{10}$ Finance \& Account Division, Grameen Euglena, Dhaka, Bangladesh, ${ }^{11}$ Al-Manar Hospital Ltd., Modern Hospital Cumilla Ltd., Dhaka, Bangladesh, ${ }^{12}$ Human Resource Department, Square Toiletries Limited, Rupayan Center, Dhaka, Bangladesh,

${ }^{13}$ Department of Physiology, Eastern Medical College, Comilla, Bangladesh, ${ }^{14}$ Department of Pharmacology, Eastern Medical College, Comilla, Bangladesh, ${ }^{15}$ Department of Anatomy, Eastern Medical College, Comilla, Bangladesh, ${ }^{16}$ WISH2ACTION Project, Handicap International, Kurigram, Bangladesh, ${ }^{17}$ Department of Periodontology and Implantology, Karnavati University, Gandhinagar, India, ${ }^{18}$ Department of Pharmacology, All India Institute of Medical Sciences, Jodhpur, India, ${ }^{19}$ Department of Pediatric Dentistry, Karnavati University, Gandhinagar, India, ${ }^{20}$ Department of Conservative Dentistry and Endodontics, Rajasthan University of Health Sciences, Jaipur, India, ${ }^{21}$ Department of Pharmacy Practice, Faculty of Pharmacy, The University of Lahore, Lahore, Pakistan, ${ }^{22}$ Pharmaceutical Administration \& PharmacoEconomics, Hanoi University of Pharmacy, Hanoi, Vietnam, ${ }^{23}$ College of Pharmacy, Seoul National University, Seoul, South Korea, ${ }^{24}$ Department of Pharmacology, College of Pharmacy, Hawler Medical University, Erbil, Iraq, ${ }^{25}$ Independent Consumer Advocate, Brunswick, VIC, Australia, ${ }^{26}$ Ghana Health Service, Keta Municipal Hospital, Pharmacy Department, Keta, Ghana, ${ }^{27}$ University of Health and Allied Sciences, School of Pharmacy, Pharmacy Practice Department, Volta Region, Ghana

Background: Countries have introduced a variety of measures to prevent and treat COVID-19 with medicines and personal protective equipment (PPE), with some countries adopting preventative strategies earlier than others. However, there has been considerable controversy surrounding some treatments. This includes hydroxychloroquine where the initial hype and misinformation lead to shortages, price rises and suicides. Price rises and shortages have also been seen for PPE. Such activities can have catastrophic effects on patients where there are high co-payment levels and issues of affordability. Consequently, there is a need to investigate this further.

Objective: Assess changes in the availability, utilization and prices of relevant medicines and PPE during the pandemic among a range of Asian countries. 
Our approach: Narrative literature review combined with interviews among community pharmacists to assess changes in consumption, prices and shortages of medicines and PPE from the beginning of March 2020 until end of May 2020. In addition, suggestions on ways to reduce misinformation.

Santosh Kumar orcid.org/0000-0002-5117-7872 Jaykaran Charan orcid.org/0000-0002-4857-6725 Siddhartha Dutta orcid.org/0000-0001-6525-5950

Jha Pallavi Abhayanand orcid.org/0000-0002-6936-3315 Rohan Bhatt orcid.org/0000-0002-7962-3918 Yesh Sharma orcid.org/0000-0003-2980-1648

Thuy Nguyen Thi Phuong orcid.org/0000-0001-7939-5276 Hye-Young Kwon orcid.org/0000-0001-9772-1354 Amanj Kurdi orcid.org/0000-0001-5036-1988 Israel Sefah orcid.org/0000-0001-6963-0519
Results: 308 pharmacists took part from five Asian countries. There was an appreciable increase in the utilization of antimicrobials in Pakistan (in over $88 \%$ of pharmacies), with lower increases or no change in Bangladesh, India, Malaysia and Vietnam. Encouragingly, there was increased use of vitamins/immune boosters and PPE across the countries, as well as limited price rises for antimicrobials in India, Malaysia and Vietnam, although greater price rises seen for analgesics and vitamin C/immune boosters. Appreciable price increases were also seen for PPE across some countries.

Conclusion: Encouraging to see increases in utilization of vitamins/immune boosters and PPE. However, increases in the utilization and prices of antimicrobials is a concern that needs addressing alongside misinformation and any unintended consequences from the pandemic. Community pharmacists can play a key role in providing evidence-based advice, helping to moderate prices, as well as helping address some of the unintended consequences of the pandemic.

\section{Keywords: Bangladesh, community pharmacists, CoVID-19, India, Malaysia, Pakistan, price rises, Vietnam}

\section{INTRODUCTION}

\section{General and Asia}

The coronavirus disease 2019 (COVID-19) pandemic was first identified in Wuhan, China, during December 2019, and by 27 September 2020 there were 32,731 million cases and over 990,000 deaths worldwide giving a case fatality ratio (CFR) among confirmed cases of $3.03 \%$ (1-3). This included over 6,721 million confirmed cases in the World Health Organization (WHO) South East Asian Region, including Bangladesh and India, with over 110,000 deaths, giving a CFR of $1.65 \%$ and the Western Pacific Region with over 600,000 reported cases and over 13,000 deaths giving a CFR of $2.187 \%$ by 27 September 2020 (1). The lower prevalence and mortality rates among the WHO Western Pacific countries, including Malaysia, Korea, and Vietnam, compared with Bangladesh, India, and Pakistan (Table 1), appears to reflect early proactive testing and lockdown policies, combined with other factors, building on the lessons learnt from earlier pandemics (Table 2), even with appreciable under-reporting in Bangladesh, India, and Pakistan (2, 4, 7, $8,12,14,15,37,50,52,56,57)$. A similar situation has been seen in Taiwan with the National Health Command Centre including the Central Epidemic Command Centre rapidly instigating educational activities, active tracking systems, accelerated production of personal protective equipment (PPE), lockdown, and quarantining measures $(58,59)$. By early April there were $<400$ confirmed cases in Taiwan among its 23 million citizens $(58,59)$, with only 513 confirmed cases by 29 September and seven deaths (60). We have also seen low prevalence and mortality rates among a number of African countries that instigated pro-active measures early compared with high income countries such as Western European countries and the USA $(1,61)$. Early engagement with citizens is crucial with preventing the spread of COVID-19 with countries such as Korea, Malaysia, Taiwan and Vietnam learning from earlier pandemics $(58,62)$. This compares with for instance Iran where the first cases of COVID-19 were confirmed on 19 February 2020 and by March 8 there were 6,566 confirmed cases and 194 deaths $(63,64)$. Some preventative measures were introduced Mid March to help reduce the spread of the virus, which included awareness campaigns, closing of educational facilities and disinfecting busy places (63-66) alongside a national screening programme but without widespread testing (64). However, stricter travel bans were only introduced at the end of March following travels during the Iranian New Year (64). This lack of early pro-activity may well have contributed to Iran having the highest prevalence rates $(443,086)$ and deaths $(25,394)$ due to COVID-19 in the WHO Eastern Mediterranean region by 27 September 2020 including Pakistan (Table 1) despite concerns with economic sanctions $(1,67,68)$.

The active tracking systems in for instance in Taiwan and Vietnam compare with Pakistan where by 3 April 2020 only 30,308 laboratory tests had been conducted of which 2,450 tested positive (9). We are aware though that over-crowding as well as a lack of clean water and sanitation in Bangladesh, India, and Pakistan will increase infection rates unless adequately addressed compared with higher income countries $(4,5,69-71)$. This is in addition to ongoing challenges with the subclinical manifestation of COVID-19 across all populations (72).

Adequate prevention and management of patients with COVID-19 is also hindered in Bangladesh, India and Pakistan compared with Malaysia, South Korea, and Vietnam, with high levels of patient co-payments to purchase medicines and other treatments, which can be catastrophic for families if members become ill $(4,73,74)$. For instance in Bangladesh, an appreciable 
TABLE 1 | Confirmed prevalence and mortality rates for COVID-19 in selected South East Asian and Western Pacific countries (27 September 2020).

\begin{tabular}{|c|c|c|c|c|c|}
\hline Country & Population size & First recorded case & Prevalence rates & Current deaths & CFR rate \\
\hline Bangladesh & $164,689,383$ & Early March 2020 (4) & 357,873 & 5,129 & $1.43 \%$ \\
\hline India & $1,380,004,385$ & 30 January $(5,6)$ & $5,992,532$ & 94,503 & $1.58 \%$ \\
\hline Malaysia & $32,365,999$ & 25 January $(7,8)$ & 10,769 & 133 & $1.24 \%$ \\
\hline Pakistan & $220,892,340$ & 25/26 February $2020(9-11)$ & 310,275 & 6,457 & $2.08 \%$ \\
\hline South Korea & $51,269,185$ & 19 January $2020(12,13)$ & 23,611 & 401 & $1.70 \%$ \\
\hline Vietnam & $97,338,579$ & First case 23 January; second wave 6 March (14-16) & 1,069 & 35 & $3.27 \%$ \\
\hline
\end{tabular}

NB: Population figures taken from Worldometer data for 2020 (17-19) and epidemiology data from WHO (1). CFR, case fatality rate.

number of households are forced to sell their assets or borrow money to fund care when family members become ill affecting care delivery (4). This typically includes the cost of medicines as seen in patients with type 2 diabetes (T2DM), where medicine costs account for $83.5 \%$ of total direct medical costs, which is typically out-of-pocket $(4,75)$. In India, up to 39 million people have been pushed into poverty each year due to healthcare copayments; however, this is beginning to change with ongoing reforms to provide health insurance coverage for up to 100 million families in poverty $(73,76-78)$. In addition, there have been recent initiatives in India to control the prices of essential medicines as well as encourage the use of generic medicines where possible $(79,80)$. Alongside this convergence of healthcare spending toward OECD average spending levels with movement toward universal healthcare in the coming years although affordability of care for the poor will remain a continuing challenge (81-84).

In Pakistan, there have been concerns with healthcare management at the provincial level following devolution, although this is not universal as seen with the recent COVID19 pandemic $(40,74,85)$. This is a concern with over $40 \%$ of the population currently living below the poverty line, and high rates of co-payments at over $78 \%$ of total healthcare expenditure with potentially catastrophic consequences if family members become ill $(74,86-88)$. The situation has been made worse in Pakistan in recent years with a rise in both infectious and noninfectious diseases. In 2019, there was a rise in the prevalence of dengue, HIV/AIDS, malaria, measles and typhoid compared to previous years, enhanced by consumption of contaminated water and food as well as environmental pollution even before the COVID-19 pandemic (89). Consequently, there are concerns that COVID-19 could further overwhelm the healthcare system. Having said this, knowledge, attitude and practices toward COVID-19 appeared satisfactory among healthcare professionals in Pakistan with a high percentage having a positive attitude toward prevention and management; however, there were some misconceptions that need to be addressed going forward $(90,91)$. There were concerns though about the extent of preventative practices among university students and employees despite good knowledge and attitudes toward COVID-19 (92).

There has also been a lack of intensive care unit (ICU) beds and ventilators among public hospitals in Bangladesh to treat patients with severe COVID-19, with a similar situation in India and Pakistan (4, 5, 9, 42, 89, 93), affecting care delivery.
We have seen countries in Africa respond to the challenge of lack of ventilators through instigating local design with the help of universities, along with increased local production of hand sanitisers and other preventative measures including face shields and splash masks to reduce the spread of the virus as well as improve management once patients are in hospital $(61,94)$ providing direction to others. Local production of essential preventative equipment is likely to grow across countries to reduce future shortages $(61,62)$. Compounding the situation in Bangladesh, India, and Pakistan, certainly with respect to available resources to fund prevention and treatment of COVID-19, are also high prevalence rates of non-communicable diseases (NCDs) including coronary vascular disease (CVD), hypertension and diabetes $(4,74,87,95-97)$. This will necessitate changing models of care with increasing use of all healthcare professionals, exacerbated by the current situation with COVID19 (98-101). This is in addition to continuing concerns with funding treatments for other infectious diseases, which, as mentioned, appear to be increasing in Pakistan (4, 76, 89, 102, 103). Alongside this, there appears a general shortage of medicines to treat diseases in Pakistan not help by concerns with affordability among manufacturers $(104,105)$.

The situation is different in Malaysia with a public healthcare system funded via general taxation in addition to a private healthcare system, which includes dispensing general practitioners $(106,107)$. The cost of medicines still accounts though for an appreciable proportion of total costs in the public healthcare system in Malaysia. There is though an active procurement process as well as demand-side measures encouraging the prescribing of generics as part of ongoing measures to help contain costs (106) similar to ongoing measures in India (79). The final agreed price for essential medicines in the public system should also ideally be no more than three times the International Reference Price (IRP) (106). However, there are currently a lack of price controls for medicines and other technologies in the private sector including mark-ups, which can add to the cost of medicines $(108,109)$. This lack of control is seen in the price of medicines for treating ischaemic heart disease (IHD) where the lowest price of generics or originator brands to treat IHD were 10.77 and 24.09 times, respectively, above IRPs, and can make these medicines unaffordable for the average worker who purchases them in community pharmacies rather than attending primary healthcare clinics (PHCs) with their long waiting times (110-112). Currently in Malaysia, community 
TABLE 2 | Early activities instigated among selected Asian countries to help with prevention and treatment of COVID-19.

\section{Country Ongoing activities including dates where known}

Bangladesh - First week of March 2020 - The Government started to postpone/cancel all mass gatherings

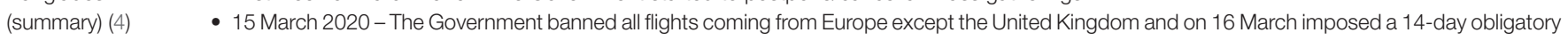
quarantine on all travelers entering Bangladesh

- 16/19 March 2020 - The Government closed all educational institutes and instructed local administrations to ban political and religious rallies as well as social and cultural gatherings

- 23 March 2020 - The Government announced the closure of all public and private offices and on 25 March declared the enforcement of lockdown measures for 10 days effective from March 26, which was further extended

- 12 June 2020 - The Government introduced the concept of risk zones for the prevention of COVID-19

- In addition, ongoing concerns with sufficient PPE; although gifts have helped

India 30 January 2020 - Surveillance strengthened at points of entry and in the community (6)

- 6 February 2020 - The Government issued travel restrictions to China and anyone with a travel history from China from 15 th January 2020 will be quarantined (20). The Ministry of Health instigated a $24 \mathrm{~h} / 7$ days-a-week disease alert helpline to provide information including clinical guidance $(21,22)$, with the textile industry producing PPE to address shortages (23)

- 8 March 2020 - 52 laboratories were identified by ICMR for undertaking testing for COVID-19 (24), now increasing and all international passengers mandated to undergo universal medical screening (24)

- 15 March 2020 - all movement suspended for foreigners through all Immigration Land Check Posts with only a few exceptions (Nepalese and Bhutanese nationals)

- 22 March 2020: "Janata Curfew" introduced with 14h lockdowns (21), all children under 10 and all elderly over 65 told to remain at home unless essential (25); Ministry of Pharma and Consumer Affairs instructed to take necessary action to regulate prices for PPE and other health related materials and to facilitate their availability in hospitals and the population (25)

- 25 March 2020 - Further lockdown measures initiated for 21 days starting on 25 March (5, 21, 26), and extended to 3 May (21)

- 14 April 2020 - Lockdown extended until 3 May 2020 (27), and further lockdown extended for 2 weeks from 4 May 2020 ; however, variable activities across districts depending on current infection rates (28)

Malaysia $\quad$ - 6 February 2020 - Updated travel restrictions from travelers coming from infected Provinces in China (29)

- February 2020 - Ministry of Health in Malaysia appreciably upgraded health facilities and diagnostic capacity including a $86 \%$ increment in diagnostics laboratory capacity, a $89 \%$ increment in ICU capacity and a 49\% increase in the number of ventilators (from 526 to 1,034 units); in addition hospitalizing all COVID-19 positive patients (8)

- 5 March 2020 - Expanded travel restriction list especially those coming from infected areas (7)

- 16/18 March 2020 - Borders closed and Malaysian citizens not allowed to leave the country; all schools, universities and non-essential businesses also closed; and control of movement $(7,30,31)$

- 25 March 2020 - Current movement restrictions extended until 14 April, with the army deployed from 22 March onwards to help enforce movement restrictions $(7,32)$

- 15 April 2020 - The Government announces it will jail movement violators (31)

- 29 April 2020 - Lockdown measures eased, e.g., easing of social distancing rules (33)

- 30 April 2020 - testing capacity increased up to 14,000 tests per day and soon up to 20,000 tests/day, building on the experience with other infectious diseases including dengue and tuberculosis (8)

- 10 May - 4 week extension to existing restrictions on movement and business until 9 June (34)

- Early June (9 June onwards) - Most restrictions lifted on businesses (35)

Overall, increasing compliance with movement restriction orders is seen as a major reason why a decrease in new COVID-19 cases was seen in Malaysia from mid-April onwards (7)

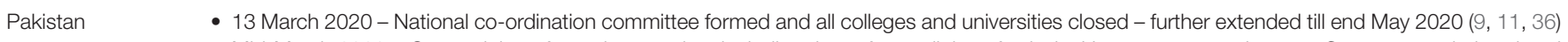

- Mid-March 2020 - Quarantining of retuning travelers including those from religious festivals. However, system in some States over whelmed and becoming centers for infection with lack of facilities including hand sanitization $(37,38)$. In addition, start of sealing of borders (Iran and Afghanistan) (36)

- Mid-March/17 March 2020 - Initially no national lockdown due to concerns with adults feeding themselves and their families if no longer working; however advice from the Ministry of Health on ways to reduce the spread of the virus including avoid public gatherings, regularly washing hands and social distancing including distancing from infected patients $(38,39)$

- Mid-March/April - Government offering financial support to citizens and businesses to help address financial concerns during the pandemic (9, 40)

- 21 March 2020 - Pakistan banned International flights (41)

- 24 March 2020 - National lockdown imposed urging citizens to stay indoors apart from food and medicines given rising prevalence rates and suspending railway operations until at least 31 March 2020. Lockdown aided by law enforcement officers and the military. Further extensions to 14 April $2020(39,41-43)$

- 9 May 2020 - Lockdown lifted principally in view of economic needs; however, concerns that lifted too soon (44, 45). More recently, targeting of "hot spots" to help control the spread $(46,47)$

South Korea $\quad$ - End January 2020 - Government establishing an emergency response committee (12)

- 27 January 2020 - Korean Centre for Disease Control (CDC) directed private companies to help produce diagnostic reagents (12). By March 100,000 kits were shipped daily and by 24 April 2020118 institutions were available to run diagnostic tests (12, 48). Screening centres were established outside of hospitals and other institutions to help track and trace the virus enabling the country to perform 300,000 tests per day by late March $(12,49)$

- 12 February 2020 - Quarantining required for travelers from Hong Kong and Macau (12)

- 21 February - Designating hospitals in Daegu for treating COVID-19 patients, and building on this (49) 
TABLE 2 | Continued

\begin{tabular}{|c|c|}
\hline Country & Ongoing activities including dates where known \\
\hline & $\begin{array}{l}\text { - Mid-February to Early March - Initiatives to double the production of masks including companies re-purposing their garment factories, with the } \\
\text { Government subsequently purchasing } 80 \% \text { of mask supplies from Korean manufacturers, banning exports and setting price limits thereby helping } \\
\text { to avert PPE shortages (12, 49,50) } \\
\text { - } 7 \text { March } 2020 \text { - GPS-App to go live to help enforce quarantining (12) } \\
\text { - } 23 \text { March } 2020 \text { - Enhanced social distancing campaign (12) } \\
\text { - } 1 \text { April } 2020 \text { - Required 14-day quarantine for all travelers with self-reporting App } \\
\text { - } 8 \text { April } 2020 \text { - Seoul closes bars, etc. (12) } \\
\text { - } 3 \text { May } 2020 \text { - Relaxation of social distancing (50) } \\
\text { - } 11 \text { May } 2020 \text { - School opening delayed apart from high school seniors (12) } \\
\text { South Korea expanded its Epidemic Intelligence Service to help with early detection and to keep rates of infection low (12) }\end{array}$ \\
\hline Vietnam & 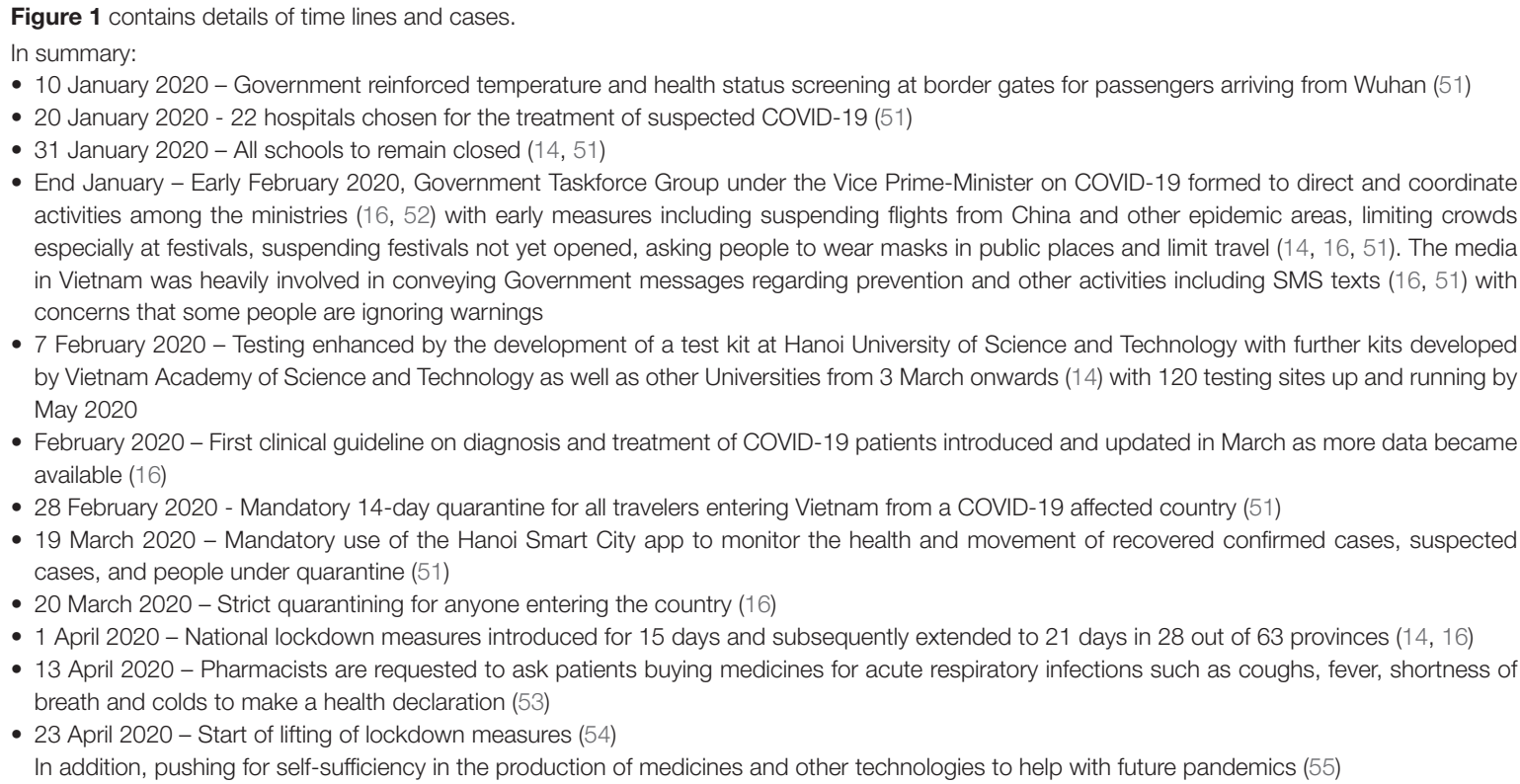 \\
\hline
\end{tabular}

pharmacists have a lesser of a role in dispensing medicines than seen in many other countries due to an appreciable number of dispensing physicians $(113,114)$. This needs to be addressed especially in patients with chronic diseases such as type 2 diabetes (T2DM) to improve their care given appreciably increased rates in recent years (115-117). In the meantime, pharmacists do have an important role in the management of acute respiratory tract infections such as coughs and colds, for gastro-intestinal ailments (118), as well as minor ailments generally (119) in Malaysia, helped by the long waiting times to see healthcare professionals in PHCs (111).

Social insurance coverage has increased in Vietnam in recent years to reduce the burden of out-of-pocket payments (120, 121). However, out-of-pocket payments still exist, with health insurance only covering part of the costs with potentially distressing consequences for a minority of families when members become ill $(120,122)$. As a result, community pharmacists continue to play a key role in managing diseases in Vietnam with for instance over $80 \%$ of people typically visiting a pharmacist first for their illness. These scenarios are common especially in rural areas to conserve costs for patients and enhance profits for pharmacists; however, rates of selfpurchasing of medicines are lower than before enhanced by increased social insurance $(113,123-125)$. Despite this, the costs of medicines can still be a concern in Vietnam with high costs vs. IRP (126).

Overall across Asia, pharmacies are often the main source of healthcare for patients given lack of waiting times, extended opening hours, and high co-payment levels $(103,115,127$ 131), mirroring the situation in other countries (132-134). Consequently, community pharmacists have a key role to play in current and future pandemics.

\section{Management Strategies to Prevent and Treat COVID-19 - General and Across Asian Countries}

COVID-19 is transmitted from person to person principally through respiratory droplets and aerosol transmission forming the basis of preventative measures across countries (Table 2) (4, 135-141). Preventative messages appear to be accepted by the population with for instance $85.8 \%$ of citizens in Pakistan in a recent survey stating they regularly wear face masks and $88.1 \%$ undertake handwashing to try and prevent the spread (10). However, as mentioned, there were concerns about the 


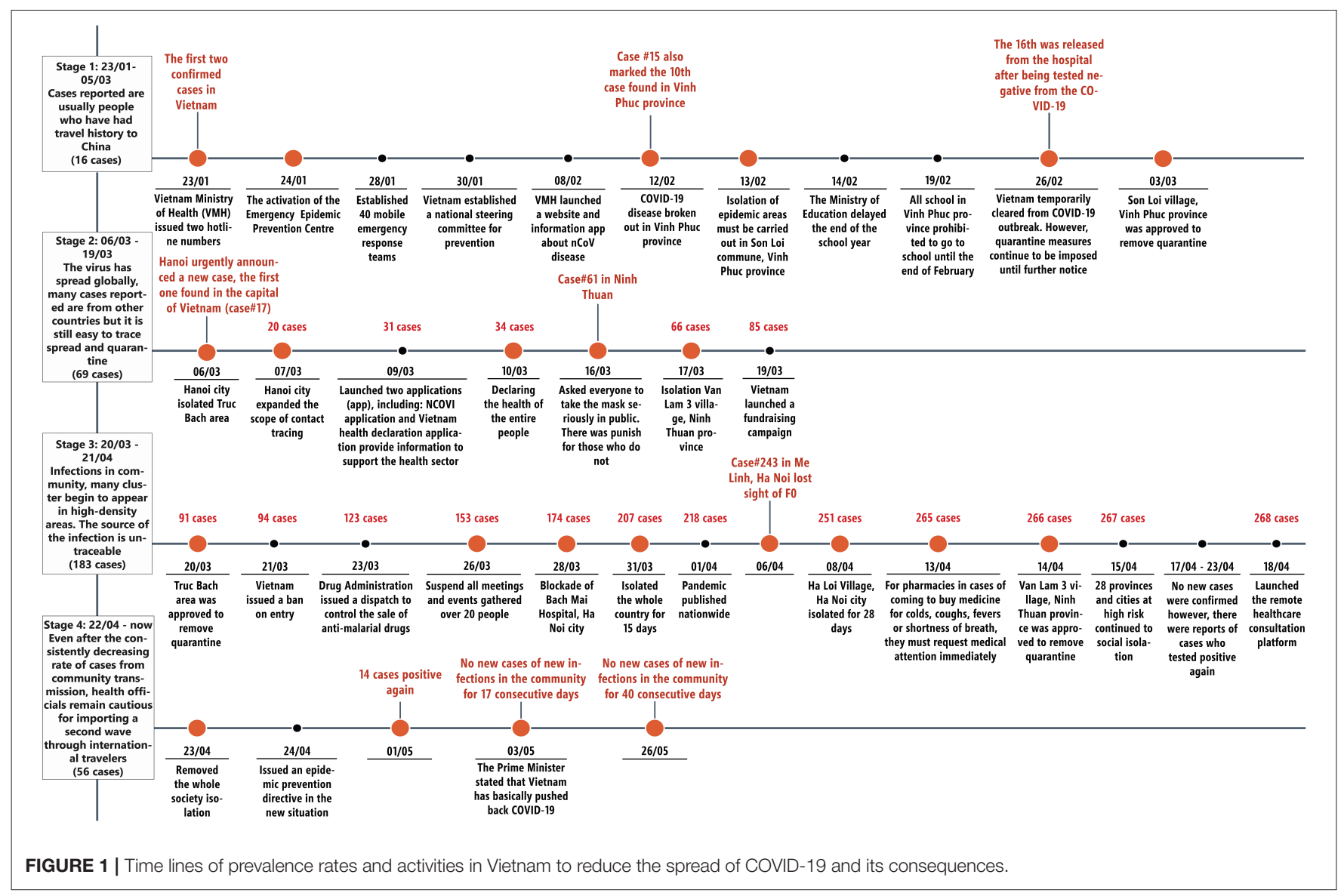

extent of preventative practices among university students and employees (92).

Current evidence suggests increased morbidity and mortality from COVID-19 is associated with underlying health conditions including hypertension, CVD, diabetes, smoking, shortness of breath, chronic obstructive pulmonary disease (COPD) and blood types (142-149). Ethnicity may also be important with patients in the United Kingdom of South Asian origin at appreciably increased risk of dying from COVID-19 vs. those of white ethnicity (150-154), which is a concern in Asia along with high rates of smoking and growing rates of chronic NCDs including CVD and diabetes (4, 95, 97, 155-157). However, currently there appears to be no cure for patients with COVID19. A number of medicines have been proposed, rejected or are still undergoing trials $(4,158-161)$. This means that preventative measures are very important to reduce morbidity and mortality from COVID-19. In addition, predictive models in hospitals to better target resources and treatments $(162,163)$.

The most promising treatment to date appears to be dexamethasone, shown in the UK Recovery Trials to reduce the number of deaths in ventilated patients and in those receiving oxygen only (164). Remdesivir has also shown encouraging results despite earlier concerns in an underpowered study (165-167), although there appears less benefit in patients with moderate COVID-19, and recent studies are questioning its role in treatment $(168,169)$. Triple antiviral therapy has also shown promise although patient numbers in the trial are small (170). Most controversy surrounds the use of chloroquine or hydroxychloroquine with or without azithromycin for prevention or treatment following initial studies in China (171173). There were concerns about the lack of comparisons in the initial studies alongside potential harm including cardiac sideeffects $(172,174,175)$. A number of recent studies have endorsed these concerns including the UK Recovery Trial (171, 176-178), resulting in the WHO and the National Institute of Health (NIH) in the US halting the use of hydroxychloroquine in their studies $(161,167,177,179,180)$. However, hydroxychloroquine is still recommended for prophylaxis in India with Chatterjee et al. (181) demonstrating that hydroxychloroquine was associated with a significant reduction in the chances of healthcare workers getting COVID-19 (21, 181, 182). The Government and others in Malaysia also initially endorsed hydroxychloroquine helped by additional supplies from India (183), with continued endorsement at lower doses in early June $(8,184,185)$, with the Government in Pakistan banning exports for fear of shortages (186), although later reversed (187). There have also been ongoing studies with chloroquine in Vietnam (188). However, hydroxychloroquine is no longer recommended in Malaysia following recent analysis of data collected from 500 cases, which showed no effect (189). 
There have been similar controversies surrounding lopinavir/ritonavir, which is endorsed in India but now dropped from the WHO Solidarity study and the UK Recovery study due to concerns with its effectiveness $(21,161,190)$. Consequently, there is a need to ensure that recommended strategies are evidence based given current controversies and redactions $(161,174,191,192)$. This is because misinformation can have devastating consequences, which include increasing the cost of medicines as well as increasing hospitalisations and deaths from poisoning from hydroxychloroquine (4, 193-196). In addition, diverting scarce monies away from purchasing necessary personal protective equipment (PPE) and monies to treat priority infectious and non-infectious diseases. Table 2 documents current prevention and other strategies among selected Asian countries to help provide future direction, building on published activities for Bangladesh (4).

Unintended consequences of COVID-19 include concerns that patients with NCDs are not attending follow-up clinics and not receiving their medicines $(4,99)$, which is an increasing concern among Asian countries including India (98, 197). In addition, concerns that the mental health of the population regarding their emotional, psychological, and social impact, is being adversely affected by the pandemic. This is likely to be the case among Asian countries with cultures highly dependent on socialization in terms of support and connectedness, with such activities appreciably affected by lockdown and other measures (198). However, we are aware that issues of mental health are being addressed through increased telemedicine approaches in lower- and middle-income countries (LMICs) (199), and this is likely to continue. Restrictions on movement with lockdown measures, as well as concerns surrounding COVID19 transmission, have also reduced immunization rates in India and Pakistan in recent months, which also needs addressing (200, 201). Community pharmacists can help here including enhancing adherence to medicines in patients with chronic NCDs as well as give guidance and public health education on prevention and possible treatments for patients with suspected COVID-19 (4, 128, 202-205).

Pharmacists and others can also help balance demand and supply of medicines, which is essential in countries where there are high patient co-payment levels and concerns with medicine availability $(4,114)$. This is particularly important if shortages lead to high prices for pertinent medicines and PPE with potentially catastrophic consequences for families.

\section{Study Objectives}

Consequently, we believe there is a need to study the availability and prices of suggested medicines and PPE to prevent and treat COVID-19 among pharmacies and drug stores in Asian countries with high rates of both infectious and noncommunicable diseases, as well as issues regarding co-payments to provide future direction. We have published on these issues in Bangladesh, and we have seen price rises in other LMICs $(4,206-208)$. We now wish to compare and contrast the findings in Bangladesh with India and Pakistan with similar high copayment levels and high rates of both infectious and noninfectious diseases, although with price controls in India (79), along with Malaysia and Vietnam where community pharmacists are active especially for minor ailments. In addition, where hydroxychloroquine has also been endorsed for the management of patients with COVID-19 certainly initially.

In addition, contrast countries where pro-active strategies initially (Table 2) appear to have appreciably lowered prevalence and mortality rates from COVID-19 (Korea, Malaysia and Vietnam) vs. Bangladesh, India, and Pakistan despite low levels of testing in these countries certainly initially (Table 1). The combined findings can help provide future direction to all key stakeholder groups.

\section{MATERIALS AND METHODS}

We adopted a similar multiple strategy approach to the paper of Haque et al. discussing activities in Bangladesh (4). This included updated information from a pragmatic review of the literature combined with a questionnaire survey among community pharmacies and drug store owners in India, Malaysia, Pakistan, and Vietnam, building on the findings in Bangladesh, to assess the current situation regarding usage patterns, prices, and availability of carefully selected medicines that could potentially be used in the management of COVID-19, as well as PPE in most countries, soon after the start of the pandemic (4). We also included herbal medicines in Pakistan and Vietnam as we are aware of their use in patients with COVID-19 among a number of LMICs despite concerns (209, 210). Medicines included pertinent antimalarials such as hydroxychloroquine, antibiotics such as azithromycin, analgesics (general including paracetamol), vitamins and immune boosters such as vitamin $\mathrm{C}$ as well as PPE including face masks (Box 1). We just asked for impressions in the first instance for changes in utilization, prices, and shortages, from early March to end of May 2020 if this was the only information available due to issues of confidentiality (4). The baseline was early 2020, i.e., just before active preventative measures in a number of the countries (Table 1). More specific data on actual changes in utilization and prices was asked if this was available; however, this did not include asking the pharmacists to break down any changes in utilization patterns and prices per month as this was deemed too problematic for this initial study.

Convenience sampling was used to select pharmacists through emails, telephone contact, personal contacts and other mechanisms. Similar to the initial study in Bangladesh (4), there was no sample size calculation as there was no previous data to base calculations upon at the start of the study. In addition, the studies undertaken in Malaysia, Pakistan, and Vietnam were pilot studies to help determine the need for additional studies. All questions were again open ended with data captured on Excel spreadsheets (Box 1). A more detailed description of the questionnaire can be found in Haque et al. (4). The replies from the community pharmacists were collated where possible into logical bands for comparisons between countries including the initial analysis from Bangladesh (4). These bands were not predefined as this was an exploratory study, with changes in prices based on local prices and not converted into a single currency such as US dollars using current exchange rates since ascertaining 
BOX 1 | Open ended questions to community pharmacists in India regarding pertinent medicines and equipment to prevent and treat COVID-19.

- Country?

- What changes in purchasing/utilization patterns have you noticed in your pharmacy from the beginning of March until the end of May 2020 for antimalarials (hydroxychloroquine), antibiotics (e.g., azithromycin and co-amoxiclav), multivitamins including Vitamin C and analgesics? The baseline is early 2020. Please base this information on invoices where possible or other information sources; otherwise, impressions

- What changes in the prices have you noticed for pertinent medicines from the beginning of March until end May 2020 for antimalarials, antibiotics, multivitamins and analgesics (based on invoices or other information sources where possible). The baseline is early 2020. Please base this information on invoices where possible or other information sources; otherwise, impressions

- Have there been any shortages for antimalarials, antibiotics, multivitamins and analgesics from the beginning of March until end May 2020 in your pharmacies? If so, what has been the extent if known?

- Similarly, for PPE including face masks, hand sanitisers and thermometers (utilization, prices, and shortages) from the beginning of March until the end May 2020 (baseline early 2020) - based again on invoices or other information sources/impressions

- Similarly for herbal medicines in Pakistan and Vietnam

- What suggestions can you give the authorities to address misinformation regarding the current pandemic (if pertinent) as well as any inappropriate self-medication with antimicrobials for future pandemics given current concerns?

TABLE 3 | Details of pharmacists and drug stores owners across the countries.

\begin{tabular}{lc}
\hline Country & Number of pharmacies/Drug stores \\
\hline Bangladesh & 170 \\
India & 111 \\
Malaysia & 12 \\
Pakistan & 9 \\
Vietnam & 6 \\
\hline Total & 308 \\
\hline
\end{tabular}

actual prices was not an objective of this study. The changes in utilization and prices were absolute changes during the time period of the study. Suggested strategies going forward for all key stakeholder groups also builds on the combined experiences of the co-authors. We have successfully used this approach before to provide future direction in LMICs $(4,125,211-215)$.

We believed that there would be price rises and shortages in other countries apart from Bangladesh. However, the nature and extent would depend on ongoing programmes within the country (Table 2) including greater price controls in India and Pakistan $(79,105)$.

Ethical approval for this study was not required according to national legislation and institutional guidelines. However, as before, all pharmacists freely provided the requested information having been given the opportunity to refuse to participate if wished. This is in line with previous studies undertaken by the co-authors in this and related areas including analysis of policies to enhance the rationale use of medicines and biosimilars, pricing policies and issues surrounding generics, which involved direct contact with health authority personnel and other key stakeholders $(4,125,212,216-219)$.

\section{RESULTS}

Table 3 provides details of the number of pharmacists and drug store owners taking part including the pilot studies in Malaysia and Vietnam. There was a low refusal rate in Bangladesh (36.1\%), India (18\%), and Malaysia (0\%), with pilot studies conducted among selected pharmacies in Pakistan and Vietnam.

We will first report on changes in utilization patterns across the studied countries before reporting on any price changes and shortages.

\section{Utilization}

Table 4 depict changes in the utilization patterns for the various medicines, vitamins and PPE from the beginning of March until the end of May 2020 among the studied countries. Encouragingly, there was no change or decreased utilization of antimalarials in an appreciable number of pharmacies in Bangladesh (51.2\%), Malaysia (83.3\%) and Vietnam, with no change in $45 \%$ of pharmacies in India, contrasting with Pakistan (no change in only 11.1\%). There were differences in the utilization patterns with antibiotics with increases seen in Bangladesh (70.6\% of stores) and Pakistan (100\% of pharmacies) compared with only $42.3 \%$ in India and little or no increase in either Malaysia or Vietnam (Table 4).

There were though appreciable increases in the utilization of analgesics and vitamin $\mathrm{C} /$ immune boosters in both Bangladesh and India, and to a lesser extent in Malaysia and Vietnam, with increased use of vitamin C/immune boosters also seen in Pakistan during the study period. Encouragingly, there were increases in the utilization of PPE across all countries where documented, some of which was substantial in line with recommendations. Encouragingly as well, no increased use of herbal medicines in Pakistan contrasting with Vietnam. It is likely that we will continue to see increases in the utilization of vitamins/immune boosters and PPE across countries if COVID-19 infection rates increase following easing of any lockdown measures.

\section{Price Changes}

Table 5 depicts price changes for pertinent medicines and PPE during the study period. Encouragingly, there were limited price increases in Malaysia and Vietnam for antimalarials and 


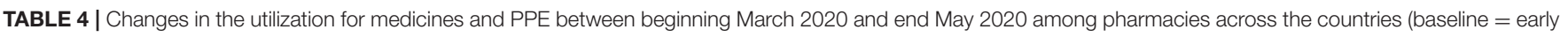
2020; $n=$ number unless specified).

\begin{tabular}{|c|c|c|c|c|c|c|c|c|c|c|c|c|c|c|c|c|}
\hline \multirow[t]{2}{*}{ Change } & \multicolumn{9}{|c|}{ Bangladesh } & \multicolumn{7}{|c|}{ India } \\
\hline & \multicolumn{2}{|r|}{ AM } & \multicolumn{2}{|c|}{ AB } & AG & \multicolumn{2}{|c|}{ Vit C } & \multicolumn{2}{|c|}{ PPE } & AM & \multicolumn{2}{|c|}{ AB } & AG & \multicolumn{2}{|c|}{ Vit C } & PPE \\
\hline Decrease/No demand (n) & \multicolumn{2}{|r|}{9} & \multicolumn{2}{|c|}{5} & 0 & \multicolumn{2}{|r|}{0} & \multicolumn{2}{|l|}{2} & 25 & \multicolumn{2}{|c|}{23} & 21 & \multicolumn{2}{|c|}{1} & 0 \\
\hline No change $(n)$ & \multicolumn{2}{|r|}{78} & \multicolumn{2}{|c|}{45} & 4 & \multicolumn{2}{|c|}{16} & \multicolumn{2}{|l|}{6} & 25 & \multicolumn{2}{|c|}{41} & 15 & \multicolumn{2}{|c|}{10} & 2 \\
\hline Increase (not specified) to slight increase $(n)$ & \multicolumn{2}{|r|}{73} & \multicolumn{2}{|c|}{104} & 142 & \multicolumn{2}{|c|}{140} & \multicolumn{2}{|c|}{139} & 59 & \multicolumn{2}{|c|}{35} & 63 & \multicolumn{2}{|c|}{81} & 54 \\
\hline High increase to under 1.5 -fold increase & \multicolumn{2}{|r|}{1} & \multicolumn{2}{|c|}{9} & 15 & & 5 & 10 & & 0 & 0 & & 0 & & 0 & 0 \\
\hline 1.5- to 3-fold increase $(n)$ & & 9 & 7 & & 9 & & 9 & 13 & & 1 & 5 & & 3 & & 1 & 3 \\
\hline 3- to 5-fold increase $(n)$ & & 0 & 0 & & 0 & & 0 & 0 & & 1 & 1 & & 6 & & 0 & 3 \\
\hline Above 5-fold increase ( $n$ ) & & 0 & 0 & & 0 & & 0 & 0 & & 0 & 6 & & 3 & & 8 & 49 \\
\hline Total number & & 170 & 17 & & 170 & & 170 & 170 & & 111 & 11 & & 111 & & 11 & 111 \\
\hline$\%$ increase & & 48.8 & 70 & & 97.6 & & 0.6 & 95.3 & & 55.0 & 42. & & 67.6 & & 0.1 & 98.2 \\
\hline$\%$ no change/decrease & & 51.2 & 29 & & 2.4 & & 9.4 & 4.7 & & 45.0 & 57. & & 32.4 & & .9 & 1.8 \\
\hline Change & & & Malays & & & & & akistar & & & & & Viet & nam & & \\
\hline & AM & AB & AG & Vit C & PPE & AM & AB & AG & Vit C & HM & AM & AB & AG & Vit C & HM & PPE \\
\hline Decrease/No demand (n) & 0 & 0 & 0 & 0 & 0 & 0 & 0 & 0 & 1 & 0 & 0 & 6 & 4 & 2 & 6 & 0 \\
\hline No change $(n)$ & 10 & 10 & 7 & 5 & 0 & 1 & 0 & 5 & 0 & 6 & 6 & 0 & 0 & 0 & 0 & 0 \\
\hline Increase (not specified) to slight increase $(n)$ & 0 & 0 & 4 & 0 & 2 & 5 & 7 & 3 & 3 & 3 & 0 & 0 & 2 & 4 & 0 & 0 \\
\hline High increase to under 1.5 -fold increase $(n)$ & 1 & 1 & 0 & 0 & 0 & 2 & 1 & 1 & 4 & 0 & 0 & 0 & 0 & 0 & 0 & 6 \\
\hline 1.5- to 3-fold increase $(n)$ & 1 & 1 & 1 & 4 & 0 & 1 & 1 & 0 & 1 & 0 & 0 & 0 & 0 & 0 & 0 & 0 \\
\hline 3- to 5-fold increase $(n)$ & 0 & 0 & 0 & 3 & 8 & 0 & 0 & 0 & 0 & 0 & 0 & 0 & 0 & 0 & 0 & 0 \\
\hline Above 5-fold increase $(n)$ & 0 & 0 & 0 & 0 & 2 & 0 & 0 & 0 & 0 & 0 & 0 & 0 & 0 & 0 & 0 & 0 \\
\hline Total number & 12 & 12 & 12 & 12 & 12 & 9 & 9 & 9 & 9 & 9 & 6 & 6 & 6 & 6 & 6 & 6 \\
\hline$\%$ increase & 16.7 & 16,7 & 41.7 & 58.3 & 100.0 & 88.9 & 100.0 & 44.4 & 88.9 & 33.2 & 0.0 & 0.0 & 33.3 & 66.7 & 0.0 & 100.0 \\
\hline$\%$ no change/decrease & 83.3 & 83.3 & 58.3 & 41,7 & 0.0 & 11.1 & 0.0 & 55.6 & 11.1 & 66.7 & 100.0 & 100.0 & 66.7 & 33.3 & 100.0 & 0.0 \\
\hline
\end{tabular}

AM, antimalarial; $A B$, Antibiotic; AG, analgesics; Vit C, Vitamin $C$ and other vitamins and immune boosters; HM, herbal medicines; PPE, Face masks, thermometers and hand sanitisers. No change also includes situations where medicines were not dispensed without a prescription or not dispensed in community pharmacies (antimalarials and antibiotics).

antibiotics, with greater price rises seen for analgesics and vitamin $\mathrm{C} /$ immune boosters. There were also very limited increases in prices in India and Pakistan enhanced by price control measures $(79,80,105)$. As expected, price rises were seen in over $90 \%$ of pharmacies for PPE across studied countries, with substantial price rises seen particularly in Bangladesh.

\section{Medicine and Prevention Shortages}

Perhaps not surprisingly, shortages of a number of medicines were seen (Table 6). This was especially the case for antimalarials in Bangladesh, India, Malaysia, and Pakistan, with shortages of antibiotics principally seen in Malaysia and Pakistan. Shortages of PPE were also seen among the countries studied reflecting ongoing preventative strategies among the countries (Table 2).

\section{Potential Ways Forward to Address Misinformation and Enhance Appropriate Use of Medicines and Equipment Across Sectors}

Possible strategies to address concerns regarding the management of COVID-19 and any unintended consequences especially in Bangladesh and India are included in Table 7. This builds on previous suggestions for Bangladesh only (4).

\section{DISCUSSION}

We believe this is one of the first studies to assess the impact of COVID-19 on the utilization, availability and price changes of pertinent medicines and PPE to prevent and treat patients with COVID-19 among Asian countries in the early stages of the pandemic. This is important as payments for medicines among a number of these LMICs can potentially be catastrophic for patients, and spending valuable resources on unproven medicines diverts scarce monies away from funding medicines in priority disease areas. Considerable increases in the prices of vitamins/immune boosters and PPE is also a concern where this exists (Table 5), again diverting monies away from funding treatments in other priority disease areas, probably reflecting some of the shortages seen (Table 6). Greater monitoring of prices as well as increases in local production of medicines and PPE may be ways forward to reduce future price rises and shortages (62), and we will continue to monitor this building on ongoing initiatives among African and Asian countries (Table 1) (61). 
TABLE 5 | Changes in the prices of medicines and PPE between beginning March 2020 and end May 2020 among pharmacies across the countries (baseline = early 2020; $n=$ number unless specified).

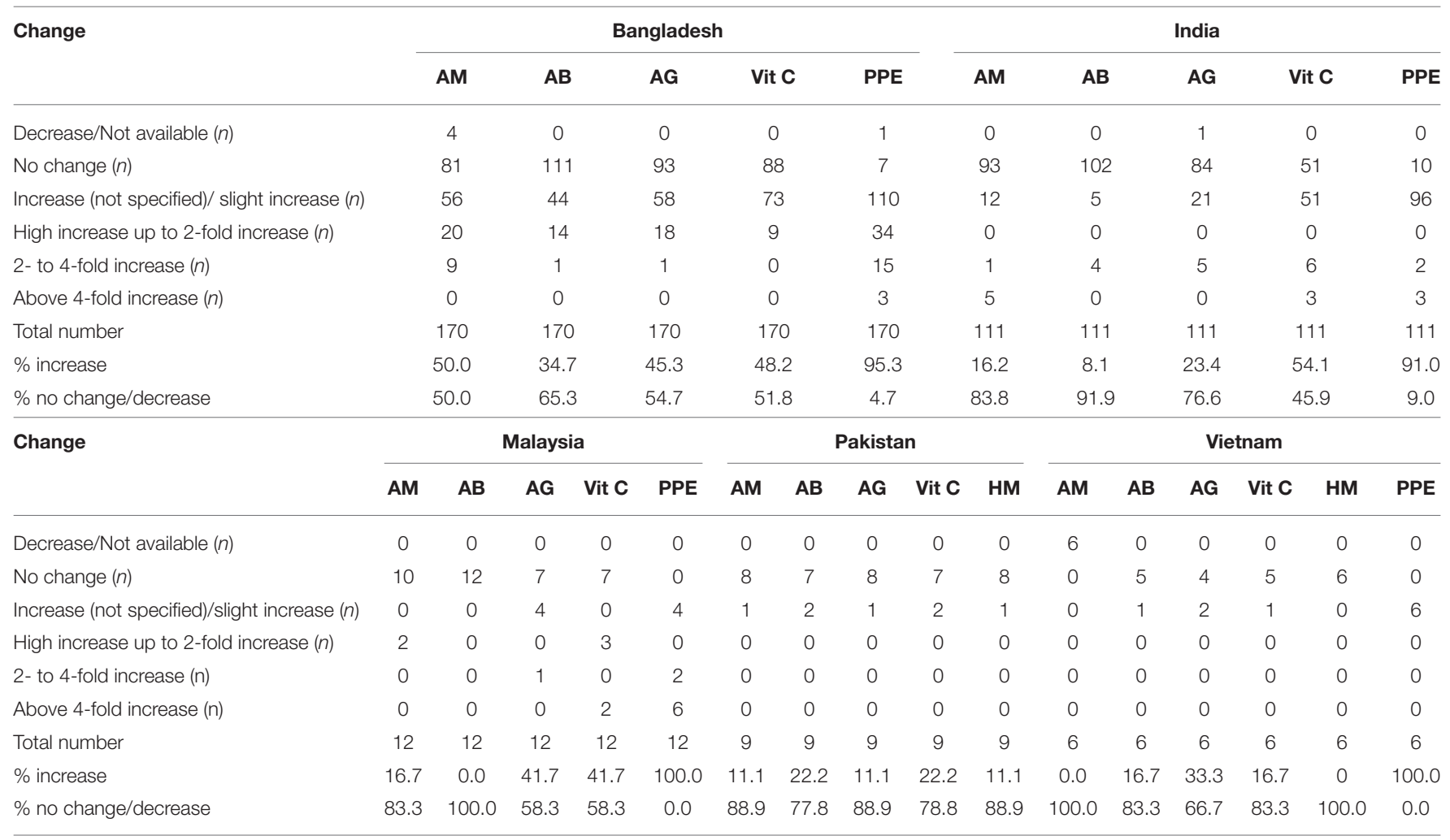

AM, antimalarial; AB, Antibiotic; AG, analgesics; Vit C, Vitamin C and other vitamins and immune boosters; HM, herbal medicines; PPE, Face masks, thermometers, and hand sanitisers.

TABLE 6 | Shortages of medicines and PPE between beginning March 2020 and end May 2020 among pharmacies across the countries (baseline = early 2020; $n=$ number unless specified).

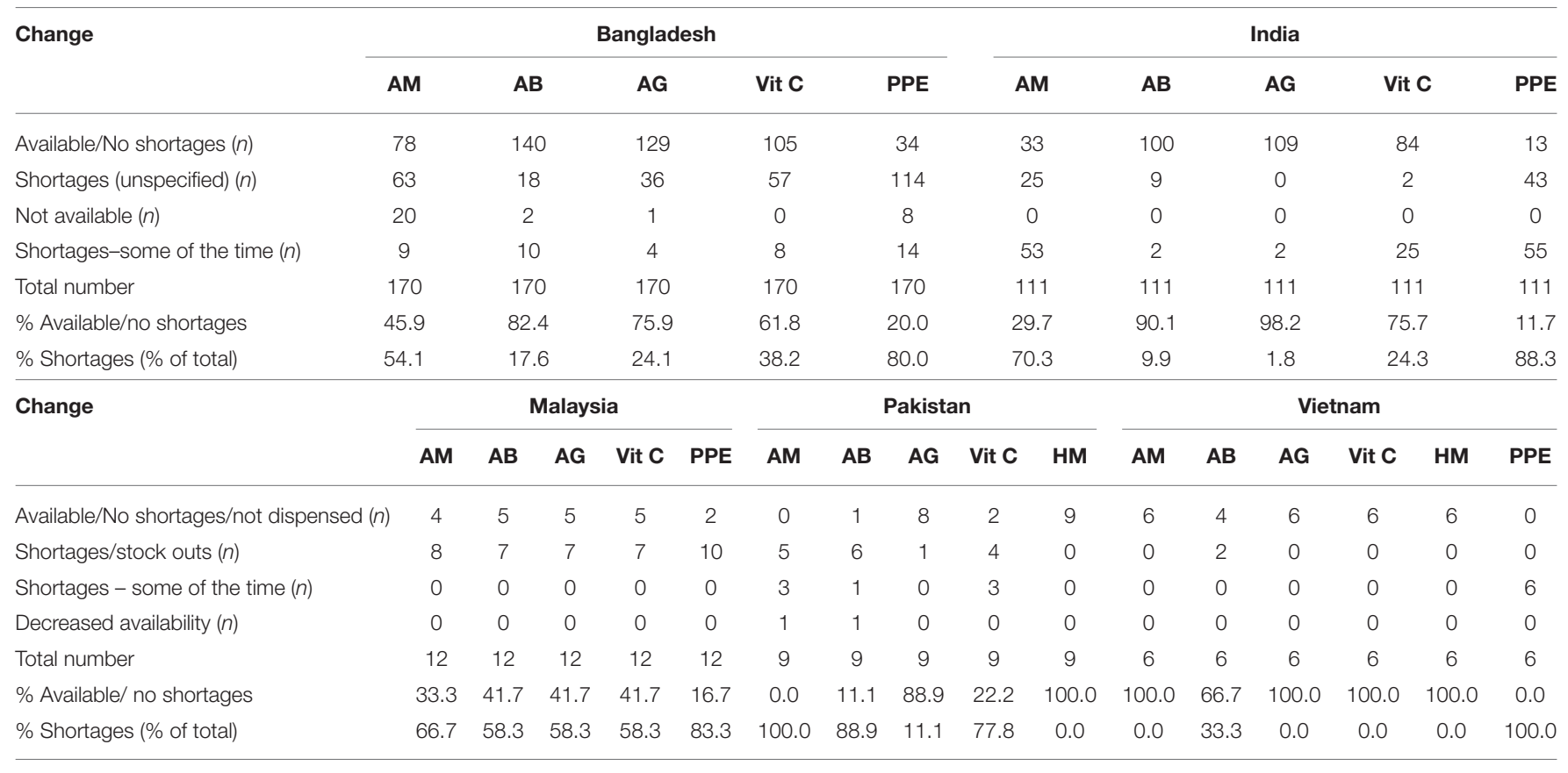

AM, antimalarial; AB, Antibiotic; AG, analgesics; Vit C, Vitamin C and other vitamins and immune boosters; HM, herbal medicines; PPE, Face masks, thermometers and hand sanitisers. 
TABLE 7 | Key activities among stakeholder groups to improve prevention and management of patients with COVID-19.

Stakeholder Suggested activities
group

Government

- Encourage early preventative measures to reduce the spread of any virus during future pandemics - building on the successes to date in Malaysia, South Korea, and Vietnam vs. Bangladesh, India and Pakistan (Tables 1, 2)

- As part of this, utilize social media and other platforms to rapidly disseminate information regarding suggested activities to prevent the spread of viruses; however, mindful of the likely situation regarding the ability to social distance and the lack of clean water in a number of households in LMICs. This builds on the findings of Hayat et al. (10) among citizens in Pakistan where following communication from the Government, in social media and other avenues, $77.0 \%$ of those surveyed believed COVID-19 could be controlled successfully with practices of wearing masks (85.8\%) and handwashing (88.1\%) common among participants (10)

- Encourage an evidence-based approach for decision making and recommendations given the controversies that still surround hydroxychloroquine (India) and Malaysia (until recently) as well as for lopinavir/ritonavir. In addition, the redaction of a number of recent papers relating to COVID-19

- Alongside this, instigate measures to reduce the level of misinformation and its effects on diverting scarce resources away from funding medicines in other priority infectious and non-infectious diseases - in line with advice and recommendations from the Council for International Organisations of Medical Sciences (220). As part of this, explore the opportunity for financial consequences for companies spreading false misinformation and claims regarding potential treatments - building on activities in other countries $(221,222)$

- Continue with ongoing and planned programmes to improve the management of patients with existing chronic NCDs as well as other infectious diseases to minimize unintended consequences arising from activities to reduce the spread of COVID-19. Alongside this, instigate activities to help reduce mental health issues, including stigma, arising from COVID-19

- Similarly, for vaccination programmes - seek to address current concerns with reduced rates as a result of the pandemic and lockdown measures

- Instigate/enforce measures to reduce inappropriate self-purchasing of medicines including antimalarials and antibiotics where concerns - building on successful measures in other countries $(125,223)$

- Instigate measures to enhance the local production of medicines and PPE to address current shortages and keep prices increases to a minimum. Investigate the potential for formal price controls building on examples in e.g., Pakistan

- When pertinent, adopt a phased approach to any easing of lockdown and other measures, with rapid re-introduction of lockdown measures if needed (224)

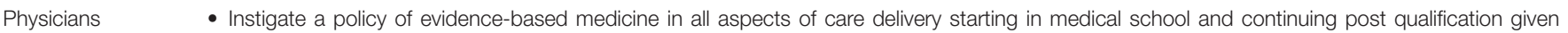
the ongoing controversies surrounding the use of hydroxychloroquine, lopinavir-ritonavir and remdesivir in the prevention and management of COVID-19

- As part of this, continue to ensure recommended treatments are evidence based through postgraduate training and other continuous professional development activities post qualification

- Continue to encourage where possible appropriate identification and management of patients with NCDs including CVD and diabetes, which includes encouraging adherence to prescribed medicines, giving rising rates of NCDs across Asia

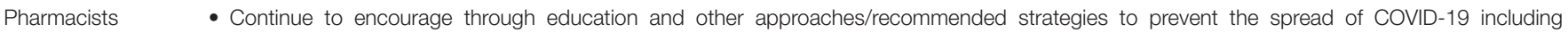
preventative measures such as PPE. This includes providing education about COVID-19 and ways to reduce the spread of the virus which includes corporate responsibilities

- Through stock control and other measures, try and ensure PPE and pertinent medicines, including suitable alternatives, that have proven to be beneficial for patients with COVID-19 are routinely available, and help ensure where possible that any price rises are kept to a minimum especially in countries with high co-payment levels

- Encourage patients to seek testing and medical advice where COVID-19 is suspected, building on current strategies in Malaysia and Vietnam (Table 2), e.g., in Vietnam pharmacists are requested to ask patients buying medicines for acute respiratory infections such as coughs, fever, shortness of breath and colds to make a health declaration (53)

- This is important since it can be difficult in practice to differentiate respiratory tract infections from COVID-19 in patients presenting with coughs and fever (225). As part of this, where pertinent, continue to argue/council patients against the need for antibiotics where concerns

- Work with patients to enhance adherence to medicines especially those for NCDs where it can be difficult for patients to attend clinics

- Potentially become involved in vaccination programmes where there is unmet need (226)

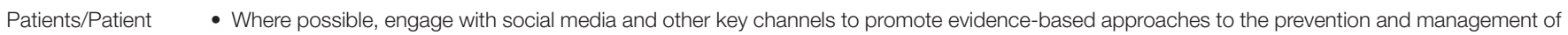
organizations

COVID-19 given the current extent of misinformation to date, and ensure messages are as clear as possible and in a positive language (224)

- In conjunction with this, seek to work with governments and other key stakeholder groups to minimize the impact of any misinformation (224) alongside working with them to seek to reduce the consequences of COVID-19 on mental health issues including any associated stigma

- Continue educating patients through various channels. This includes the importance of self-management and adherence to prescribed treatments in patients with chronic NCDs - given the challenges of clinic attendance arising from lockdown measures. Explore new technologies including telemedicine and other approaches to reduce reliance on clinic attendance especially during pandemics as well as among rural patients in LMICs

CVD, cardiovascular disease; LMICs, low- and middle-income countries; NB: NCDs, non-communicable diseases; PPE, personal protective equipment.

It was encouraging to see appreciable increases in the utilization of PPE as well as Vitamin C/immune boosters across the studied countries (Table 4) suggesting that public health messages are getting through, building on positive experiences in Pakistan $(10,90)$. Alongside this, it was encouraging to see no change or decreased utilization of antimalarials and antibiotics in an appreciable number of pharmacies in India, Malaysia and Pakistan, similarly for antimalarials in Bangladesh. This is in line with initiatives by governments certainly in India, Malaysia, and Vietnam to try and restrict the sales of antimicrobials to reduce resistance development, which we see continuing. There are a number of initiatives that can be undertaken in Bangladesh and Pakistan to enhance the appropriate use of antimicrobials. This includes providing increased education and guidelines to pharmacists where there are concerns $(129,227)$, as well as greater patient education. In addition, greater enforcement of any legislation banning the dispensing of antimicrobials without a prescription. Such activities have worked well in other 
countries including other LMICs $(125,132,228-230)$ without the need for fines, which can be problematic and difficult to enforce (223). This is important in patients with COVID-19 since, as mentioned (Table 7), it can be difficult in practice to differentiate respiratory tract infections from COVID-19 in patients presenting with coughs and fever (225). Consequently, early referral for testing and subsequent management is encouraged where possible.

The increased use of analgesics across a number of the countries studied is also in line with expectations (Table 4), and as mentioned, we would expect increased utilization of vitamins/immune boosters and PPE to continue if COVID-19 infection rates increase following any easing of lockdown measures.

Table 7 highlights potential activities that can be undertaken by key stakeholder groups going forward including addressing unintended consequences. A key area is the level of misinformation seen especially surrounding chloroquine and hydroxychloroquine with potentially devastating consequences (193, 196, 231, 232). Consequently, as mentioned, there is a need to ensure that recommended strategies from Minsteries of Health and leading physician and pharmacy organizations are evidence based given the extent of redactions and concerns that have been seen to date $(161,174,191,192)$. Another key area from a public health viewpoint is addressing the unintended consequences of lockdown measures. This includes an increase in other infectious diseases if immunization programmes and other measures are not undertaken as well as an increase in mental health disorders and other NCDs as a result of the pandemic $(99,100,198,200,201)$. We are aware that lockdown measures in sub-Saharan Africa could result in up to 18 million additional cases of malaria and up to 30,000 additional deaths (233-235), with similar concerns in infected Asian countries. There are also considerable concerns with appreciably increased mortality in other infectious diseases if children are not being vaccinated (236). Consequently, avoided if possible. Telemedicine and other approaches can help with mental health concerns as well as concerns with other NCDs in LMICs (199), and this is likely to continue. However, mindful that any approach needs to take into account individual patient's needs and their specific situation (237).

Community pharmacists are likely to have an increasing role in the future across countries including LMICs as their knowledge and experience grows. This includes potentially instigating educational and other programmes to enhance adherence to medicines in patients with chronic NCDs given ongoing concerns as well as give guidance and public health education on prevention and possible treatments for patients with suspected COVID-19 (4, 128, 202-205). Their potential role also includes helping with immunization programmes with studies showing that when pharmacists provide immunizations, they substantially increase rates (226). Community pharmacists can also push for extended prescription lengths where this is a concern and patients have difficulties with obtaining supplies. We will be exploring the unintended consequences in future research projects as these considerations are important in future planning.

\section{LIMITATIONS}

We are aware of a number of limitations with this study. These include the fact that we were only able to undertake pilot studies in a number of countries including Pakistan and Vietnam. In addition, we were unable to obtain exact details on changes in the utilization and prices of pertinent medicines and PPEs from all the pharmacists visited due to issues of confidentiality and having the data readily to hand. We were also unable to undertake any time series analysis as we were primarily interested in changes post the pandemic, and this was not broken down by month. As a result, we did not adjust for any seasonality. However, we are confident our findings and ways forward for all key stakeholder groups can be helpful for future planning purposes including extending the role of community pharmacists across countries.

\section{CONCLUSION}

We have seen increases in utilization and prices for antimalarials and antibiotics across countries arising from the COVID-19 pandemic, with considerable increases in some countries. This needs addressing through educational and other activities to prevent rises in resistance rates. Community pharmacies and others, including patient organizations, can also play a key role with improving prevention measures as well as reducing the impact of any misinformation given the consequences experienced among countries.

Key stakeholder groups including community pharmacists and patient organizations can also help address the unintended consequences from lockdown and other activities including potential increases in infectious diseases and greater morbidity from NCDs, and we will be monitoring this in the future. Encouragingly, there was increased use of vitamins/immune boosters and PPE among the Asian countries. However, the considerable price rises seen are a concern in countries with existing high co-payment levels and no government control on prices, which need addressing. Community pharmacists can again play a role here alongside the Government.

\section{DATA AVAILABILITY STATEMENT}

The raw data supporting the conclusions of this article will be made available by the authors, without undue reservation.

\section{ETHICS STATEMENT}

Ethical approval for this study was not required according to national legislation and institutional guidelines. However, as before, all pharmacists freely provided the requested information having been given the opportunity to refuse to participate if wished.

\section{AUTHOR CONTRIBUTIONS}

All authors listed have made a substantial, direct and intellectual contribution to the work, and approved it for publication. 


\section{REFERENCES}

1. WHO. Coronavirus Disease (COVID-19) Situation Report. (2020). Available online at: https://www.who.int/docs/default-source/coronaviruse/situationreports/20200928-weekly-epi-update.pdf?sfvrsn=9e354665_4 (accessed September 29, 2020).

2. Wu Z, McGoogan JM. Characteristics of and Important Lessons From the Coronavirus Disease 2019 (COVID-19) Outbreak in China: summary of a report of 72314 cases from the Chinese Center for Disease Control and Prevention. JAMA. (2020) 323:1239-42. doi: 10.1001/jama.2020.2648

3. Li Q, Guan X, Wu P, Wang X, Zhou L, Tong Y, et al. Early transmission dynamics in Wuhan, China, of novel coronavirus-infected pneumonia. $N$ Engl J Med. (2020) 382:1199-207. doi: 10.1056/NEJMoa2001316

4. Haque M, Islam S, Iqbal S, Urmi UL, Kamal ZM, Shuvo SA, et al. Availability and price changes of potential medicines and equipment for the prevention and treatment of COVID-19 among pharmacy and drug stores in Bangladesh; findings and implications. Bang J Med Sci. (2020) 19:S36-50. doi: 10.3329/bjms.v19i0.48106

5. Kamath S, Kamath R, Salins P. COVID-19 pandemic in India: challenges and silver linings. Postgrad Med J. (2020) 96:422-3. doi: 10.1136/postgradmedj-2020-137780

6. WHO India. Novel Coronavirus Disease (COVID-19) Situation Update Report - 1. (2020). Available online at: https://www.who.int/docs/defaultsource/wrindia/india-situation-report-1.pdf?sfvrsn=5ca2a672_0 (accessed September 28, 2020).

7. Tang KHD. Movement control as an effective measure against Covid19 spread in Malaysia: an overview. Zeitschrift Gesundheitswissenschaften. (2020) 1-4. doi: 10.1007/s10389-020-01316-w

8. Director-General of Health Malaysia. The Malaysian Response to COVID19: Building Preparedness for 'Surge Capacity', Testing Efficiency, and Containment. (2020). Available online at: https://kpkesihatan.com/2020/ 06/16/the-malaysian-response-to-covid-19-building-preparedness-forsurge-capacity-testing-efficiency-and-containment/ (accessed September $28,2020)$.

9. Relief Web. Pakistan COVID-19 Weekly Situation Report No. 2. (2020). Available online at: https://reliefweb.int/sites/reliefweb.int/files/resources/ UNICEF\%20Pakistan\%20CoViD-19\%20Situation\%20Report\%20No.\%202 \%20-\%2030\%20March-5\%20April\%202020.pdf (accessed September 28, 2020).

10. Hayat K, Rosenthal M, Xu S, Arshed M, Li P, Zhai P, et al. View of Pakistani residents toward coronavirus disease (COVID-19) during a rapid outbreak: a rapid online survey. Int J Environ Res Public Health. (2020) 17:3347. doi: 10.3390/ijerph17103347

11. Nafees M, Khan F. Pakistan's response to COVID-19 pandemic and efficacy of quarantine and partial lockdown: a review. Electron J Gen Med. (2020) 17:em240. doi: 10.29333/ejgm/7951

12. Exemplars in Global Health. Emerging COVID-19 Success Story: South Korea Learned the Lessons of MERS. (2020). Available online at: https:// ourworldindata.org/covid-exemplar-south-korea (accessed September 29, 2020).

13. Report on the Epidemiological Features of Coronavirus Disease 2019 (COVID-19) outbreak in the Republic of Korea from January 19 to March 2 2020. J Kor Med Sci. (2020) 35:e112. doi: 10.3346/jkms.2020.35.e112

14. Thwaites G, Rabaa M, Choisy M, van Doorn R, Luong DH, Quang Tan DQ, et al. Emerging COVID-19 Success Story: Vietnam's Commitment to Containment. (2020). Available online at: https://ourworldindata.org/covidexemplar-vietnam (accessed September 27, 2020).

15. Hoang VM, Hoang HH, Khuong QL, La NQ, Tran TTH. Describing the pattern of the COVID-19 epidemic in Vietnam. Glob Health Action. (2020) 13:1776526. doi: 10.1080/16549716.2020.1776526

16. Ha BTT, Ngoc Quang L, Mirzoev T, Tai NT, Thai PQ, Dinh PC. Combating the COVID-19 epidemic: experiences from Vietnam. Int J Environ Res Public Health. (2020) 17:3125. doi: 10.3390/ijerph17093125

17. Worldometer. South-Eastern Asia by Population. (2020). Available online at: https://www.worldometers.info/world-population/south-eastern-asiapopulation/ (accessed September 29, 2020).

18. Worldometer. Eastern Asia by Population. (2020). Available online at: https:// www.worldometers.info/world-population/eastern-asia-population/
19. Worldometer. Southern Asia by Population. (2020). Available online at: https://www.worldometers.info/world-population/southern-asiapopulation/ (accessed September 29, 2020).

20. WHO India. Novel Coronavirus Disease (COVID-19) Situation Update Report - 2. (2020). Available online at: https://www.who.int/docs/defaultsource/wrindia/india-situation-report-2.pdf?sfvrsn=962f294b_0 (accessed September 29, 2020).

21. Kumar SU, Kumar DT, Christopher BP, Doss CGP. The rise and impact of COVID-19 in India. Front Med. (2020) 7:250. doi: 10.3389/fmed.2020.00250

22. Ministry of Health and Family Welfare Government of India. COVID19 India. (2020). Available online at: https://www.mohfw.gov.in/ (accessed September 28, 2020).

23. Bhattacharya S, Hossain M, Singh A. Addressing the shortage of personal protective equipment during the COVID-19 pandemic in India-A public health perspective. AIMS Public Health. (2020) 7:223-7. doi: 10.3934/publichealth.2020019

24. WHO India. Novel Coronavirus Disease (COVID-19) Situation Update Report - 6. (2020). Available online at: https://www.who.int/ docs/default-source/wrindia/situation-report/india-situation-report6606711da860b4d38b266c91265952977.pdf?sfvrsn=2f6c5c95_2 (accessed September 28, 2020).

25. WHO India. Novel Coronavirus Disease (COVID-19) Situation Update Report - 8. (2020). Available online at: https://www.who.int/ docs/default-source/wrindia/situation-report/india-situation-report8bc9aca340f91408b9efbedb3917565fc.pdf?sfvrsn=5e0b8a43_2 (accessed September 29, 2020).

26. Press Information Bureau Government of India Ministry of Home Affairs Government of India Issues Orders Prescribing Lockdown for Containment of COVID-19 Epidemic in the Country. (2020). Available online at: https:// pib.gov.in/newsite/PrintRelease.aspx?relid=200655 (accessed September 28, 2020).

27. Prime Minister's Office. Text of PM's Address to the Nation. (2020). Available online at: https://pib.gov.in/PressReleseDetail.aspx?PRID= 1614215 (accessed September 27, 2020).

28. Ministry of Home Affairs India. Extension of Lockdown for a further period of Two Weeks with effect from May 4 2020. (2020). Available online at: https:// pib.gov.in/PressReleasePage.aspx?PRID=1620095 (accessed September 28, 2020).

29. GardaWorld. New Travel Restrictions Introduced. (2020). Available online at: https://www.garda.com/crisis24/news-alerts/312061/malaysia-newtravel-restrictions-introduced-february-6-update-2 (accessed September 27, 2020).

30. GardaWorld. Malaysia: Government Closes Borders to All Foreigners Over COVID-19 Concerns March 18 /Update 5. (2020). Available online at: https:// www.garda.com/crisis24/news-alerts/323221/malaysia-government-closesborders-to-all-foreigners-over-covid-19-concerns-march-18-update- 5 (accessed September 29, 2020).

31. HRW News. Malaysia: Stop Jailing Covid-19 Lockdown Violators. (2020). Available online at: https://www.hrw.org/news/2020/04/26/malaysia-stopjailing-covid-19-lockdown-violators (accessed September 28, 2020).

32. GardaWorld. Malaysia: Prime Minister Extends Movement Control Order to April 14 /update 8. (2020). Available online at: https://www.garda.com/ crisis24/news-alerts/326221/malaysia-prime-minister-extends-movementcontrol-order-to-april-14-update- 8 (accessed September 29, 2020).

33. GardaWorld. Malaysia: Authorities Announce Easing of COVID-19 Social Distancing Restrictions From April 29/update 17. (2020). Available online at: https://www.garda.com/crisis24/news-alerts/337541/malaysia-authoritiesannounce-easing-of-covid-19-social-distancing-restrictions-from-april29-update-17 (accessed September 27, 2020).

34. GardaWorld. Malaysia: Authorities Extend COVID-19 Business and Movement Restrictions Until June 9/update 20. (2020). Available online at: https://www.garda.com/crisis24/news-alerts/340661/malaysia-authoritiesextend-covid-19-business-and-movement-restrictions-until-june- 9 update-20 (accessed September 27, 2020).

35. Reuters. Malaysia to Ease Most Lockdown Measures, Coronavirus 'Under Control'. (2020). Available online at: https://english.alarabiya.net/en/ coronavirus/2020/06/07/Malaysia-to-ease-most-lockdown-measurescoronavirus- under-control- (accessed September 25, 2020). 
36. Gul A. Rising COVID-19 Cases Pose Challenge to Pakistan's Crumbling Health Care System. (2020). Available online at: https://www.voanews. com/south-central-asia/rising-covid-19-cases-pose-challenge-pakistanscrumbling-health-care-system (accessed September 25, 2020).

37. Mangi F. Pakistan's Fragile Health System Faces a Viral Catastrophe. (2020). Available online at: https://www.bloomberg.com/news/articles/2020-04-08/ pakistan-s-fragile-health-system-faces-a-viral-catastrophe

38. DW. Coronavirus: Is Pakistan Taking COVID-19 Too Lightly? (2020). Avaialble online at: https://www.dw.com/en/coronavirus-is-pakistantaking-covid-19-too-lightly/a-52824403 (accessed September 28, 2020).

39. Economist. India and Pakistan Try to Keep a Fifth of Humanity at Home. (2020). Available online at: https://www.economist.com/asia/2020/03/26/ india-and-pakistan-try-to-keep-a-fifth-of-humanity-at-home (accessed September 25, 2020).

40. Younus U. Coronavirus Hits Pakistan's Already-Strained Economy, and Its Most Vulnerable. (2020). Available online at: https://www.atlanticcouncil. org/blogs/new-atlanticist/coronavirus-hits-pakistans-already-strainedeconomy-and-its-most-vulnerable/ (accessed September 26, 2020).

41. Council on Foreign Relations. Coronavirus in South Asia, March 24, 2020: Outbreak in Pakistan and India on Lockdown. (2020). Available online at: https://www.cfr.org/blog/coronavirus-south-asia-march-24-2020outbreak-pakistan-and-india-lockdown (accessed September 25, 2020).

42. Kakar AH, Siddique A. Pakistan Faces Unprecedented Healthcare Crisis Amid Mounting Coronavirus Infections. (2020). Available online at: https://gandhara.rferl.org/a/pakistan-faces-unprecedented-healthcarecrisis-amid-mounting-coronavirus-infections/30679490.html (accessed September 26, 2020).

43. Sajid I, Latif A. Pakistan Stays Under Lockdown Amid Coronavirus Outbreak. (2020). Available online at: https://www.aa.com.tr/en/asia-pacific/pakistanstays- under-lockdown-amid-coronavirus-outbreak/1777394 (accessed September 27, 2020).

44. Greenfield C, Farooq U. After Pakistan's Lockdown Gamble, COVID-19 Cases Surge. (2020). Available online at: https://uk.reuters.com/article/us-healthcoronavirus-pakistan-lockdown/after-pakistans-lockdown-gamble-covid19-cases-surge-idUKKBN23C0NW (accessed September 27, 2020).

45. Daily Sabah. Pakistan Ends COVID-19 Lockdown Even as Infections Tick Higher. (2020). Available online at: https://www.dailysabah.com/world/asiapacific/pakistan-ends-covid-19-lockdown-even-as-infections-tick-higher

46. Hashim A. 'Smart lockdown' in Pakistan to Target 500 Coronavirus Hotspots. (2020). Available online at: https://www.aljazeera.com/news/2020/06/ lockdown-pakistan-target-500-coronavirus-hotspots- 200623072202544. html (accessed September 27, 2020).

47. Farmer B. Pakistan Seals Off Virus 'hot-spots' in New Lockdown Strategy That Aims to Minimise Economic Damage. (2020). Available online at: https://www.telegraph.co.uk/global-health/science-and-disease/pakistanseals-virus-hot-spots-new-lockdown-strategy-aims-minimise/ (accessed September 26, 2020).

48. Fisher M, Sang-Hun C. How South Korea Flattened the Curve. New York Times (2020). Available online at: https://www.nytimes.com/2020/03/23/ world/asia/coronavirus-south-korea-flatten-curve.html

49. Kim J-H, An J A-R, Min P-K, Bitton A, Gawande AA. How South Korea Responded to the Covid-19 Outbreak in Daegu. NEJM Catal. (2020) 1:1-14. doi: 10.1056/CAT.20.0159

50. Kim K, Lee K-S, Lee J. South Korea's COVID-19 Response: Hard Lessons on Saving Lives. (2020). Available online at: https://devpolicy.org/south-koreascovid-19-response-20200609-1/ (accessed September 27, 2020).

51. Pham QT, Rabaa MA, Luong DH, Tan DQ, Quang TD, Quach H-L et al. The first 100 days of SARS-CoV-2 control in Vietnam. Clin Infect Dis. (2020). doi: 10.1093/cid/ciaa1130. [Epub ahead of print].

52. Dabla-Norris E, Gulde-Wolf A-M, Painchaud F. Vietnam's Success in Containing COVID-19 Offers Roadmap for Other Developing Countries. (2020). Available online at: https://www.imf.org/en/News/Articles/2020/06/ 29/na062920-vietnams-success-in-containing-covid19-offers-roadmapfor-other-developing-countries (accessed September 27, 2020).

53. Vietnam Insider. Hanoi Asks Pharmacies to Report People Buying Medicines for Covid-19-Like Symptoms. (2020). Available online at: https:// vietnaminsider.vn/hanoi-asks-pharmacies-to-report-people-buyingmedicines-for-covid-19-like-symptoms/ (accessed September 25, 2020).
54. Pearson J, Nguyen P. Vietnam to Ease Nationwide Coronavirus Lockdown. (2020). Available online at: https://uk.reuters.com/article/uk-healthcoronavirus-vietnam/vietnam-to-ease-nationwide-coronavirus-lockdownidUKKCN2241LD (accessed September 26, 2020).

55. Thuy N. Vietnam Pushes for Medicine Self-Sufficiency Post Covid-19: Fitch Solutions. (2020). Available online at: http://hanoitimes.vn/vietnam-pushesfor-medicine-self-sufficiency-post-covid-19-fitch-solutions-312399.html

56. WHO. Coronavirus Disease (COVID-19) Situation Report - 172. (2020). Available online at: https://www.who.int/docs/default-source/coronaviruse/ situation-reports/20200710- covid-19-sitrep-172.pdf?sfvrsn=70724b90_2 (accessed September 27, 2020).

57. Tanzeem A. COVID-19 Deaths, Patients Grossly Under-Reported in Pakistan. (2020). Available online at: https://www.voanews.com/covid-19-pandemic/ covid-19-deaths-patients-grossly-under-reported-pakistan (accessed September 27, 2020).

58. Wang CJ, Ng CY, Brook RH. Response to COVID-19 in Taiwan: big data analytics, new technology, and proactive testing. JAMA. (2020) 323:1341-2. doi: 10.1001/jama.2020.3151

59. Wang T. How Has Taiwan Kept Its Coronavirus Infection Rate So Low? (2020). Available online at: https://www.dw.com/en/taiwan-coronavirus/a52724523 (accessed September 25, 2020).

60. Worldometer. Taiwan (2020). Available online at: https://www.worldometers. info/coronavirus/country/taiwan/ (accessed September 27, 2020).

61. Ogunleye OO, Basu D, Mueller D, Sneddon J, Seaton RA, Yinka-Ogunleye $\mathrm{AF}$, et al. Response to the novel corona virus (COVID-19) pandemic across Africa: successes, challenges, and implications for the future. Front Pharmacol. (2020) 11:1205. doi: 10.3389/fphar.2020.01205

62. Hopman J, Allegranzi B, Mehtar S. Managing COVID-19 in low- and middleincome countries. JAMA. (2020) 323:1549-50. doi: 10.1001/jama.2020.4169

63. Abdi M. Coronavirus disease 2019 (COVID-19) outbreak in Iran: actions and problems. Infect Control Hosp Epidemiol. (2020) 41:754-5. doi: $10.1017 /$ ice. 2020.86

64. Salimi R, Gomar R, Heshmati B. The COVID-19 outbreak in Iran. J Glob Health. (2020) 10:010365. doi: 10.7189/jogh.10.010365

65. Moftakhar L, Seif M. The exponentially increasing rate of patients infected with COVID-19 in Iran. Arch Iran Med. (2020) 23:235-8. doi: 10.34172/aim.2020.03

66. Raoofi A, Takian A, Akbari Sari A, Olyaeemanesh A, Haghighi H, Aarabi M. COVID-19 pandemic and comparative health policy learning in Iran. Arch Iran Med. (2020) 23:220-34. doi: 10.34172/aim.2020.02

67. Murphy A, Abdi Z, Harirchi I, McKee M, Ahmadnezhad E. Economic sanctions and Iran's capacity to respond to COVID-19. Lancet Public Health. (2020) 5:e254. doi: 10.1016/S2468-2667(20)30083-9

68. Takian A, Raoofi A, Kazempour-Ardebili S. COVID-19 battle during the toughest sanctions against Iran. Lancet. (2020) 395:1035-6. doi: 10.1016/S0140-6736(20)30668-1

69. Saaliq S. Limited Access to Clean Water Among India's Poor Spawns Coronavirus Concerns. (2020). Available online at: https://news.yahoo.com/ limited-access-clean-water-among-130525398.html (accessed September 27, 2020).

70. Dutta PK. Challenge to Fighting Coronavirus in India: $36 \%$ Wash Hands With Soap Before a Meal. (2020). Available online at: https://www.indiatoday.in/ coronavirus-outbreak/story/challenge-to-fighting-coronavirus-in-india36-wash-hands-with-soap-before-a-meal-1660295-2020-03-27 (accessed September 26, 2020).

71. Abdullah A, Arif M, Macktoom S, Saleem A, Toheed M, Anwar NH, et al. Why the Covid-19 Crisis Is an Urban Crisis. (2020). Available online at: https://www.dawn.com/news/1544933 (accessed September 27, 2020).

72. Song JY, Yun JG, Noh JY, Cheong HJ, Kim WJ. Covid-19 in South Korea challenges of subclinical manifestations. N Engl J Med. (2020) 382:1858-9. doi: 10.1056/NEJMc2001801

73. Selvaraj S, Farooqui HH, Karan A. Quantifying the financial burden of households' out-of-pocket payments on medicines in India: a repeated crosssectional analysis of National Sample Survey data 1994-2014. BMJ Open. (2018) 8:e018020. doi: 10.1136/bmjopen-2017-018020

74. Khan SA. Situation analysis of health care system of Pakistan: post 18 amendments. Health Care Curr Rev. (2019) 7:244. doi: $10.35248 / 2375-4273.19 .07 .244$ 
75. Afroz A, Alam K, Ali L, Karim A, Alramadan MJ, Habib SH, et al. Type 2 diabetes mellitus in Bangladesh: a prevalence based cost-of-illness study. BMC Health Serv Res. (2019) 19:601. doi: 10.1186/s12913-019-4440-3

76. Kastor A, Mohanty SK. Disease-specific out-of-pocket and catastrophic health expenditure on hospitalization in India: Do Indian households face distress health financing? PLoS ONE. (2018) 13:e0196106. doi: 10.1371/journal.pone.0196106

77. Reddy KS. Health care reforms in India. JAMA. (2018) 319:2477-8. doi: 10.1001/jama.2018.5284

78. Sood N, Wagner Z. JAMA Health Forum. India's Historic Effort to Expand Health Insurance to Individuals Living Below the Poverty Line. (2020). Available online at: https://jamanetwork.com/channels/healthforum/fullarticle/2763530 (accessed September 25, 2020).

79. Pavithra KM. Explainer: Are Medicine Prices Controlled in India? (2019). Available online at: https://factly.in/explainer-are-medicine-pricescontrolled-in-india/ (accessed September 27, 2020).

80. HealthWorld. Fixing Drug Prices Helped Consumers Save Rs 5,060 Crore: Government. (2016). Available online at: https://health.economictimes. indiatimes.com/news/pharma/fixing-drug-prices-helped-consumers-savers-5060-crore-government/55562102 (accessed September 26, 2020).

81. Jakovljevic M, Getzen TE. Growth of global health spending share in low and middle income Countries. Front Pharmacol. (2016) 7:21. doi: 10.3389/fphar.2016.00021

82. Jakovljevic M, Potapchik E, Popovich L, Barik D, Getzen TE. Evolving health expenditure landscape of the BRICS Nations and Projections to 2025. Health Econ. (2017) 26:844-52. doi: 10.1002/hec.3406

83. Jakovljevic M, Timofeyev Y, Ekkert NV, Fedorova JV, Skvirskaya G, Bolevich $S$, et al. The impact of health expenditures on public health in BRICS nations. J Sport Health Sci. (2019) 8:516-9. doi: 10.1016/j.jshs.2019.09.002

84. Jakovljevic M, Timofeyev Y, Ranabhat CL, Fernandes PO, Teixeira JP, Rancic $\mathrm{N}$, et al. Real GDP growth rates and healthcare spending - comparison between the G7 and the EM7 countries. Global Health. (2020) 16:64. doi: 10.1186/s12992-020-00590-3

85. Zaidi SA, Bigdeli M, Langlois EV, Riaz A, Orr DW, Idrees N, et al. Health systems changes after decentralisation: progress, challenges and dynamics in Pakistan. BMJ Global Health. (2019) 4:e001013. doi: 10.1136/bmjgh-2018-001013

86. Pakistan Today. Pakistan's Healthcare System. (2020). Available online at: https://www.pakistantoday.com.pk/2020/01/08/pakistans-healthcaresystem/ (accessed September 27, 2020).

87. Datta BK, Husain MJ, Asma S. Assessing the relationship between out-ofpocket spending on blood pressure and diabetes medication and household catastrophic health expenditure: evidence from Pakistan. Int J Equity Health. (2019) 18:9. doi: 10.1186/s12939-018-0906-x

88. Hsu J, Flores G, Evans D, Mills A, Hanson K. Measuring financial protection against catastrophic health expenditures: methodological challenges for global monitoring. Int J Equity Health. (2018) 17:69. doi: 10.1186/s12939-018-0749-5

89. Ahmed T. Story of Neglect: Another Grim Year for Healthcare in Pakistan. (2020). Available online at: https://tribune.com.pk/story/2129467/storyneglect-another-grim-year-healthcare-pakistan (accessed September 25, 2020).

90. Salman M, Mustafa Z, Asif N, Zaidi HA, Shehzadi N, Khan TM, et al. Knowledge, attitude and preventive practices related to COVID-19 among health professionals of Punjab province of Pakistan. J Infect Dev Countr. (2020) 14:707-12. doi: 10.3855/jidc.12878

91. Malik UR, Atif N, Hashmi FK, Saleem F, Saeed H, Islam M, et al. Knowledge, attitude, and practices of healthcare professionals on COVID-19 and risk assessment to prevent the epidemic spread: a multicenter cross-sectional study from Punjab, Pakistan. Int J Environ Res Public Health. (2020) 17:6395. doi: 10.3390/ijerph17176395

92. Salman M, Mustafa ZU, Asif N, Zaidi HA, Hussain K, Shehzadi N, et al. Knowledge, attitude and preventive practices related to COVID-19: a crosssectional study in two Pakistani university populations. Drugs Ther Perspect. (2020). doi: 10.1007/s40267-020-00737-7. [Epub ahead of print].

93. Roy A, Ghoshal D, Kalra A. More Patients Than Beds in Mumbai as India Faces Surge in Virus Cases. (2020). Available online at: https:// uk.reuters.com/article/uk-health-coronavirus-ndia-medics-insig/more- patients-than-beds-in-mumbai-as-india-faces-surge-in-virus-casesidUKKBN23103D (accessed September 27, 2020)..

94. Afriyie DK, Asare GA, Amponsah SK, Godman B. COVID-19 pandemic in resource-poor countries: challenges, experiences and opportunities in Ghana. J Infect Dev Countr. (2020) 14:838-43. doi: 10.3855/jidc.12909

95. India State-Level Disease Burden Initiative Diabetes C. The increasing burden of diabetes and variations among the states of India: the Global Burden of Disease Study 1990-2016. Lancet Global Health. (2018) 6:e135262. doi: 10.1016/S2214-109X(18)30387-5

96. Ramakrishnan S, Zachariah G, Gupta K, Shivkumar Rao J, Mohanan PP, Venugopal K, et al. Prevalence of hypertension among Indian adults: results from the great India blood pressure survey. Indian Heart J. (2019) 71:309-13. doi: 10.1016/j.ihj.2019.09.012

97. India State-Level Disease Burden Initiative CVDC. The changing patterns of cardiovascular diseases and their risk factors in the states of India: the Global Burden of Disease Study 1990-2016. Lancet Global Health. (2018) 6:e133951. doi: 10.1016/S2214-109X(18)30407-8

98. Jakovljevic M, Jakab M, Gerdtham U, McDaid D, Ogura S, Varavikova E, et al. Comparative financing analysis and political economy of noncommunicable diseases. J Med Econ. (2019) 22:722-7. doi: 10.1080/13696998.2019.1600523

99. Kluge HHP, Wickramasinghe K, Rippin HL, Mendes R, Peters DH, Kontsevaya A, et al. Prevention and control of non-communicable diseases in the COVID-19 response. Lancet. (2020) 395:1678-80. doi: 10.1016/S0140-6736(20)31067-9

100. Basu S. Non-communicable disease management in vulnerable patients during Covid-19. Indian J Med Ethics. (2020) 5:103-5. doi: 10.20529/IJME.2020.041

101. Kayali M, Moussally K, Lakis C, Abrash MA, Sawan C, Reid A, et al. Treating Syrian refugees with diabetes and hypertension in Shatila refugee camp, Lebanon: Médecins Sans Frontières model of care and treatment outcomes. Conflict Health. (2019) 13:12. doi: 10.1186/s13031-019-0191-3

102. Farooqui HH, Selvaraj S, Mehta A, Heymann DL. Community level antibiotic utilization in India and its comparison vis-à-vis European countries: evidence from pharmaceutical sales data. PLoS ONE. (2018) 13:e0204805. doi: 10.1371/journal.pone.0204805

103. Daftary A, Satyanarayana S, Jha N, Singh M, Mondal S, Vadnais C, et al. Can community pharmacists improve tuberculosis case finding? A mixed methods intervention study in India. BMJ Global Health. (2019) 4:e001417. doi: 10.1136/bmjgh-2019-001417

104. Atif M, Malik I, Mushtaq I, Asghar S. Medicines shortages in Pakistan: a qualitative study to explore current situation, reasons and possible solutions to overcome the barriers. BMJ Open. (2019) 9:e027028. doi: 10.1136/bmjopen-2018-027028

105. Lee KS, Shahidullah A, Zaidi STR, Patel RP, Ming LC, Tariq MH, et al. The crux of the medicine prices' controversy in Pakistan. Front Pharmacol. (2017) 8:504. doi: 10.3389/fphar.2017.00504

106. Shafie AA, Chandriah H, Yong YV, Wan Puteh SE. Health technology assessment and its use in drug policy in Malaysia. Value Health Reg Issues. (2019) 18:145-50. doi: 10.1016/j.vhri.2019.03.003

107. Hassali MA, Kamil TK, Md Yusof FA, Alrasheedy AA, Yusoff ZM, Saleem $\mathrm{F}$, et al. General practitioners' knowledge, attitude and prescribing of antibiotics for upper respiratory tract infections in Selangor, Malaysia: findings and implications. Exp Rev Anti Infect Ther. (2015) 13:511-20. doi: 10.1586/14787210.2015.1012497

108. Ahmad NS, Islahudin F. Affordability of essential medicine prices in Malaysia's private health sector. Patient Pref Adher. (2018) 12:1231-7. doi: 10.2147/PPA.S151603

109. Ahmad NS, Hatah E, Makmor-Bakry M. Association between medicine Price declaration by pharmaceutical industries and retail prices in Malaysia's private healthcare sector. J Pharm Policy Pract. (2019) 12:15. doi: 10.1186/s40545-019-0176-Z

110. You HW, Tajuddin NSA, Anwar YAS. Measuring availability, prices and affordability of ischaemic heart disease medicines in Bangi, Selangor, Malaysia. Malays J Med Sci. (2019) 26:113-21. doi: $10.21315 / \mathrm{mjms} 2019.26 .5 .10$

111. Rezal RS, Hassali MA, Alrasheedy AA, Saleem F, Yusof FA, Kamal $M$, et al. Prescribing patterns for upper respiratory tract infections: a prescription-review of primary care practice in Kedah, Malaysia, 
and the implications. Exp Rev Anti Infect Ther. (2015) 13:1547-56. doi: 10.1586/14787210.2015.1085303

112. Puteh SEW, Ahmad SNA, Aizuddin AN, Zainal R, Ismail R. Patients' willingness to pay for their drugs in primary care clinics in an urbanized setting in Malaysia: a guide on drug charges implementation. Asia Pac Fam Med. (2017) 16:5. doi: 10.1186/s12930-017-0035-5

113. Hassali MA. Role of community pharmacists in medication management: current and future prospects in Asia. JAS4QoL. (2017) 3 1:1-18. Available online at: http://as4qol.org

114. Cadogan CA, Hughes CM. On the frontline against COVID-19: Community pharmacists' contribution during a public health crisis. Res Soc Administr Pharm. (2020). doi: 10.1016/j.sapharm.2020.03.015. [Epub ahead of print].

115. Lee EL, Wong PS, Tan MY, Sheridan J. What role could community pharmacists in Malaysia play in diabetes self-management education and support? The views of individuals with type 2 diabetes. Int J Pharm Pract. (2018) 26:138-47. doi: 10.1111/ijpp.12374

116. Kho BP, Hassali MA, Lim CJ, Saleem F. Challenges in the management of community pharmacies in Malaysia. Pharm Pract. (2017) 15:933. doi: 10.18549/PharmPract.2017.02.933

117. Rahim FF, Abdulrahman SA, Kader Maideen SF, Rashid A. Prevalence and factors associated with prediabetes and diabetes in fishing communities in penang, Malaysia: a cross-sectional study. PLoS ONE. (2020) 15:e0228570. doi: 10.1371/journal.pone.0228570

118. Mathews A, Azad AK, Abbas SA, Bin Che Rose FZ, Helal Uddin ABM. Study on the perception of staff and students of a University on Community Pharmacy Practice in Ipoh, Perak, Malaysia. J Pharm Bioall Sci. (2018) 10:226-31. doi: 10.4103/JPBS.JPBS_80_18

119. Selvaraj A, Redzuan AM, Hatah E. Community pharmacists' perceptions, attitudes and barriers towards pharmacist-led minor ailment services in Malaysia. Int J Clin Pharm. (2020) 42:777-85. doi: 10.1007/s11096-020-00973-x

120. Lee H-Y, Oh J, Hoang VM, Moon JR, Subramanian SV. Use of highlevel health facilities and catastrophic expenditure in Vietnam: can health insurance moderate this relationship? BMC Health Serv Res. (2019) 19:318. doi: 10.1186/s12913-019-4115-0

121. Hoa NT, Tam NM, Derese A, Markuns JF, Peersman W. Patient experiences of primary care quality amongst different types of health care facilities in central Vietnam. BMC Health Serv Res. (2019) 19:275. doi: 10.1186/s12913-019-4089-y

122. Pekerti A, Vuong Q-H, Ho TM, Vuong T-T. Health care payments in Vietnam: patients' Quagmire of caring for health versus economic destitution. Int $J$ Environ Res Public Health. (2017) 14:1118. doi: 10.3390/ijerph14101118

123. Ha TV, Nguyen AMT, Nguyen HST. Self-medication practices among Vietnamese residents in highland provinces. J Multidiscip Healthcare. (2019) 12:493-502. doi: 10.2147/JMDH.S211420

124. Nguyen HH, Ho DP, Vu TLH, Tran KT, Tran TD, Nguyen TKC, et al. "I can make more from selling medicine when breaking the rules" - understanding the antibiotic supply network in a rural community in Viet Nam. BMC Public Health. (2019) 19:1560. doi: 10.1186/s12889-019-7812-z

125. Godman B, Haque M, McKimm J, Abu Bakar M, Sneddon J, Wale J, et al. Ongoing strategies to improve the management of upper respiratory tract infections and reduce inappropriate antibiotic use particularly among lower and middle-income countries: findings and implications for the future. Curr Med Res Opin. (2020) 36:301-27. doi: 10.1080/03007995.2019.1700947

126. Nguyen TA, Knight R, Mant A, Razee H, Brooks G, Dang TH, et al. Inflated medicine prices in Vietnam: a qualitative study. Health Policy Plan. (2017) 32:647-56. doi: 10.1093/heapol/czw174

127. Mohathasim Billah A, Venkatesan P. A self-limited survey on community pharmacies in India, the services offered, facilities available to make ease of compliance for the medication prescribed over the counter medication in view of pharmacists: J Pharm Sci Res. (2017) 9:314-7. Available online at: http://www.jpsr.pharmainfo.in/Documents/Volumes/ vol9Issue03/jpsr09031709.pdf

128. Abdulsalim S, Unnikrishnan MK, Manu MK, Alrasheedy AA, Godman B, Morisky DE. Structured pharmacist-led intervention programme to improve medication adherence in COPD patients: a randomized controlled study. Res Soc Admin Pharm. (2018) 14:909-14. doi: 10.1016/j.sapharm.2017.10.008
129. Saleem Z, Hassali MA, Hashmi FK, Godman B, Saleem F. Antimicrobial dispensing practices and determinants of antimicrobial resistance: a qualitative study among community pharmacists in Pakistan. Fam Med Commun Health. (2019) 7:e000138. doi: 10.1136/fmch-2019-000138

130. Hermansyah A, Sainsbury E, Krass I. Community pharmacy and emerging public health initiatives in developing Southeast Asian countries: a systematic review. Health Social Care Commun. (2016) 24:e11-22. doi: $10.1111 / \mathrm{hsc} .12289$

131. Khanal S, Nissen L, Veerman L, Hollingworth S. Pharmacy workforce to prevent and manage non-communicable diseases in developing nations: The case of Nepal. Res Soc Admin Pharm. (2016) 12:655-9. doi: 10.1016/j.sapharm.2015.09.005

132. Markovic-Pekovic V, Grubisa N, Burger J, Bojanic L, Godman B. Initiatives to reduce nonprescription sales and dispensing of antibiotics: findings and implications. J Res Pharm Pract. (2017) 6:120-5. doi: 10.4103/jrpp.JRPP_17_12

133. Sousa Pinto G, Bader L, Billberg K, Criddle D, Duggan C, El Bizri L, et al. Beating non-communicable diseases in primary health care: the contribution of pharmacists and guidance from FIP to support WHO goals. Res Soc Admin Pharm. (2020) 16:974-7. doi: 10.1016/j.sapharm.2019.10.008

134. Akutey R, Der R, Owusu-Daaku F, Baiden F. Using community pharmacies to expand access to screening for noncommunicable diseases in suburban Ghana-A facility-based survey on client needs and acceptability. Health Sci Rep. (2018) 1:e79. doi: 10.1002/hsr2.79

135. World Health Organisation. Operational CONSIDERATIONs for Case Management of COVID-19 in Health Facility and Community: Interim Guidance. (2020). Available online at: https://apps.who.int/iris/handle/ 10665/331492 (accessed September 27, 2020).

136. WHO. Modes of Transmission of Virus Causing COVID-19: Implications for IPC Precaution Recommendations. (2020). Available online at: https://www.who.int/news-room/commentaries/detail/modes-oftransmission- of-virus-causing-covid-19-implications-for-ipc-precautionrecommendations (accessed September 25, 2020).

137. Ng Y, Li Z, Chua YX, Chaw WL, Zhao Z, Er B, et al. Evaluation of the effectiveness of surveillance and containment measures for the first 100 patients with COVID-19 in Singapore - January 2-February 292020. MMWR. (2020) 69:307-11. doi: 10.15585/mmwr.mm6911e1

138. Haque M. Combating COVID-19: a coordinated efforts of healthcare providers and policy makers with global participation are needed to achieve the desired goals. Bang J Med Sci. (2020). 19:47610. doi: 10.3329/bjms.v19i0.47610

139. Pradhan D, Biswasroy P, Kumar Naik P, Ghosh G, Rath G. A review of current interventions for COVID-19 prevention. Arch Med Res. (2020) 51:363-74. doi: 10.1016/j.arcmed.2020.04.020

140. Anderson EL, Turnham P, Griffin JR, Clarke CC. Consideration of the aerosol transmission for COVID-19 and public health. Risk Anal. (2020) 40:902-7. doi: 10.1111/risa.13500

141. Klompas M, Baker MA, Rhee C. Airborne transmission of SARS-CoV-2: theoretical considerations and available evidence. JAMA. (2020) 324:441-2. doi: $10.1001 /$ jama.2020.12458

142. Vardavas CI, Nikitara K. COVID-19 and smoking: a systematic review of the evidence. Tobacco Induced Dis. (2020) 18:20. doi: 10.18332/tid/119324

143. Aghagoli G, Gallo Marin B, Soliman LB, Sellke FW. Cardiac involvement in COVID-19 patients: risk factors, predictors, and complications: a review. $J$ Cardiac Surg. (2020) 35:1302-5. doi: 10.1111/jocs.14538

144. Richardson S, Hirsch JS, Narasimhan M, Crawford JM, McGinn T, Davidson $\mathrm{KW}$, et al. Presenting characteristics, comorbidities, and outcomes among 5700 patients hospitalized with COVID-19 in the New York City Area. JAMA. (2020) 323:2052-9. doi: 10.1001/jama.2020.6775

145. Huang I, Lim MA, Pranata R. Diabetes mellitus is associated with increased mortality and severity of disease in COVID-19 pneumonia - A systematic review, meta-analysis, and meta-regression. Diabetes Metab Syndr. (2020) 14:395-403. doi: 10.1016/j.dsx.2020.04.018

146. Zheng Z, Peng F, Xu B, Zhao J, Liu H, Peng J, et al. Risk factors of critical \& mortal COVID-19 cases: a systematic literature review and meta-analysis. $J$ Infect. (2020) 81:e16-25. doi: 10.1016/j.jinf.2020.04.021

147. Alqahtani JS, Oyelade T, Aldhahir AM, Alghamdi SM, Almehmadi M, Alqahtani AS, et al. Prevalence, severity and mortality associated 
with COPD and smoking in patients with COVID-19: a rapid systematic review and meta-analysis. PLoS ONE. (2020) 15:e0233147. doi: 10.1371/journal.pone. 0233147

148. Ellinghaus D, Degenhardt F, Bujanda L, Buti M, Albillos A, Invernizzi P, et al. Genomewide association study of severe Covid-19 with respiratory failure. $N$ Engl J Med. (2020) 383:1522-34. doi: 10.1056/NEJMoa2020283

149. Zhao J, Yang Y, Huang H, Li D, Gu D, Lu X, et al. Relationship between the ABO Blood Group and the COVID-19 susceptibility. Clin Infect Dis. (2020). doi: 10.1093/cid/ciaa1150. [Epub ahead of print].

150. Sonwalkar P. Covid-19: Indians, Non-whites in UK More at Risk of Death. (2020). Available online at: https://www.hindustantimes.com/indiansabroad/covid-19-indians-non-whites-in-uk-more-at-risk-of-death/storyaDtiNXMxE1xJJaPwSX9t4O.html (accessed September 27, 2020).

151. Public Health England. Disparities in the Risk and Outcomes of COVID19. (2020). Available online at: https://assets.publishing.service.gov. uk/government/uploads/system/uploads/attachment_data/file/892085/ disparities_review.pdf (accessed September 27, 2020).

152. Khunti K, Singh AK, Pareek M, Hanif W. Is ethnicity linked to incidence or outcomes of covid-19? BMJ. (2020) 369:m1548. doi: 10.1136/bmj.m1548

153. Kirby T. Evidence mounts on the disproportionate effect of COVID19 on ethnic minorities. Lancet Respir Med. (2020) 8:547-8. doi: 10.1016/S2213-2600(20)30228-9

154. El-Khatib Z, Jacobs GB, Ikomey GM, Neogi U. The disproportionate effect of COVID-19 mortality on ethnic minorities: genetics or health inequalities? EClinicalMedicine. (2020) 23:100430. doi: 10.1016/j.eclinm.2020.100430

155. Mohan P, Lando HA, Panneer S. Assessment of tobacco consumption and control in India. Indian J Clin Med. (2018) 9:1179916118759289. doi: $10.1177 / 1179916118759289$

156. WHO. Cardiovascular diseases (CVD) in Viet Nam. (2020). Available online at: https://www.who.int/vietnam/health-topics/cardiovascular-diseases (accessed September 27, 2020).

157. Ministry of Health. Clinical Practice Guidelines - Primary \& Secondary Prevention of Cardiovascular Disease. (2017). Available online at: https:// www.moh.gov.my/moh/resources/Penerbitan/CPG/CARDIOVASCULAR/ 3.pdf (accessed September 25, 2020).

158. Sanders JM, Monogue ML, Jodlowski TZ, Cutrell JB. Pharmacologic treatments for coronavirus disease 2019 (COVID-19): a review. JAMA. (2020) 323:1824-36. doi: 10.1001/jama.2020.6019

159. Md Insiat Islam R. Current drugs with potential for treatment of COVID-19: a literature review. J Pharm Pharm Sci. (2020) 23:58-64. doi: $10.18433 /$ jpps 31002

160. Dhama K, Khan S, Tiwari R, Sircar S, Bhat S, Malik YS, et al. Coronavirus Disease 2019 -COVID-19. Clin Microbiol Rev. (2020) 33:e00028-20. doi: 10.1128/CMR.00028-20

161. WHO. WHO Discontinues Hydroxychloroquine and Lopinavir/Ritonavir Treatment Arms for COVID-19. (2020). Available online at: https:// www.who.int/news-room/detail/04-07-2020-who-discontinues-

hydroxychloroquine-and-lopinavir- ritonavir-treatment-arms-for-covid- 19 (accessed September 27, 2020).

162. Bartoletti M, Giannella M, Scudeller L, Tedeschi S, Rinaldi M, Bussini $\mathrm{L}$, et al. Development and validation of a prediction model for severe respiratory failure in hospitalized patients with SARS-CoV-2 infection: a multicentre cohort study (PREDI-CO study). Clin Microbiol Infect. (2020) doi: 10.2139/ssrn.3588558. [Epub ahead of print].

163. Liang W, Liang H, Ou L, Chen B, Chen A, Li C, et al. Development and validation of a clinical risk score to predict the occurrence of critical illness in hospitalized patients with COVID-19. JAMA Intern Med. (2020) 180:1081-9. doi: 10.1001/jamainternmed.2020.2033

164. Horby P, Lim WS, Emberson JR, Mafham M, Bell JL, Linsell L, et al. Dexamethasone in hospitalized patients with Covid-19 - preliminary report. N Engl J Med. (2020). doi: 10.1101/2020.06.22.20137273. [Epub ahead of print].

165. Beigel JH, Tomashek KM, Dodd LE, Mehta AK, Zingman BS, Kalil AC, et al. Remdesivir for the treatment of Covid-19 - final report. N Engl J Med. (2020). doi: 10.1056/NEJMoa2007764. [Epub ahead of print].

166. Wang Y, Zhang D, Du G et al. Remdesivir in adults with severe COVID19: a randomised, double-blind, placebo-controlled, multicentre trial. Lancet. (2020) 395:1569-78. doi: 10.1016/S0140-6736(20)31022-9
167. ECDC. ECDC - Vaccines and Treatment of COVID-19. (2020). Available online at: https://www.ecdc.europa.eu/en/covid-19/latest-evidence/ vaccines-and-treatment (accessed September 25, 2020).

168. Spinner CD, Gottlieb RL, Criner GJ, Arribas López JR, Cattelan AM, Soriano Viladomiu A, et al. Effect of remdesivir vs standard care on clinical status at 11 days in patients with moderate COVID-19: a randomized clinical trial. JAMA. (2020) 324:1048-57. doi: 10.1001/jama.2020.16349

169. Dyer O. Covid-19: Remdesivir has little or no impact on survival, WHO trial shows. BMJ. (2020) 371:m4057. doi: 10.1136/bmj.m4057

170. Hung IF-N, Lung K-C, Tso E Y-K, Liu R, Chung T W-H, Chu M-Y, et al. Triple combination of interferon beta-1b, lopinavir-ritonavir, and ribavirin in the treatment of patients admitted to hospital with COVID19: an open-label, randomised, phase 2 trial. Lancet. (2020) 395:1695-704. doi: 10.1016/S0140-6736(20)31042-4

171. Boulware DR, Pullen MF, Bangdiwala AS, Pastick KA, Lofgren SM, Okafor EC, et al. A randomized trial of hydroxychloroquine as postexposure prophylaxis for Covid-19. N Engl J Med. (2020) 383:517-25. doi: 10.1056/NEJMoa2016638

172. Gautret P, Lagier JC, Parola P, Hoang VT, Meddeb L, Mailhe M, et al. Hydroxychloroquine and azithromycin as a treatment of COVID-19: results of an open-label non-randomized clinical trial. Int J Antimicrob Agents. (2020) 56:105949. doi: 10.1016/j.ijantimicag.2020.105949

173. Cortegiani A, Ingoglia G, Ippolito M, Giarratano A, Einav S. A systematic review on the efficacy and safety of chloroquine for the treatment of COVID-19. J Crit Care. (2020) 57:279-83. doi: 10.1016/j.jcrc.2020. 03.005

174. International Society of Antimicrobial Chemotherapy. Official Statement from International Society of Antimicrobial Chemotherapy (ISAC) Hydroxychloroquine Azithromycin as a Treatment of COVID-19: Results of an Open-Label Non-Randomized Clinical Trial (Gautret $P$ et al. PMID. (3220)5204). Available online at: https://www.isac.world/news-andpublications/official-isac-statement (accessed September 25, 2020).

175. Ferner RE, Aronson JK. Chloroquine and hydroxychloroquine in covid-19. BMJ. (2020) 369:m1432. doi: 10.1136/bmj.m1432

176. Geleris J, Sun Y, Platt J, Zucker J, Baldwin M, Hripcsak G, et al. Observational study of hydroxychloroquine in hospitalized patients with Covid-19. N Engl J Med. (2020) 382:2411-8. doi: 10.1056/NEJMoa2012410

177. Horby P, Mafham M, Linsell L, Bell JL, Staplin N, Emberson JR, et al. Effect of hydroxychloroquine in hospitalized patients with Covid-19. N Engl J Med. (2020). doi: 10.1056/NEJMoa2022926. [Epub ahead of print].

178. Rosenberg ES, Dufort EM, Udo T, Wilberschied LA, Kumar J, Tesoriero J, et al. Association of treatment with hydroxychloroquine or azithromycin with in-hospital mortality in patients with COVID-19 in New York State. JAMA. (2020) 323:2493-502. doi: 10.1001/jama.2020.8630

179. WHO. Solidarity trial consortium. Repurposed antiviral drugs for COVID-19 - interim WHO Solidarity trial results. MedRxiv. (2020). doi: 10.1101/2020.10.15.20209817 (accessed October 25, 2020).

180. NIH. NIH Halts Clinical Trial of Hydroxychloroquine. (2020). Available online at: https://www.nhlbi.nih.gov/news/2020/nih-halts-clinical-trialhydroxychloroquine

181. Chatterjee P, Anand T, Singh KJ, Rasaily R, Singh R, Das S, et al. Healthcare workers \& SARS-CoV-2 infection in India: A case-control investigation in the time of COVID-19. Indian J Med Res. (2020) 151:459-67. doi: 10.4103/ijmr.IJMR_2234_20

182. Tilangi P, Desai D, Khan A, Soneja M. Hydroxychloroquine prophylaxis for high-risk COVID-19 contacts in India: a prudent approach. Lancet Infect Dis. (2020) 20:1119-20. doi: 10.1016/S1473-3099(20) 30430-8

183. Sibbal S. India Approves Malaysia's Request for Supplying Hydroxychloroquine Drug to Deal With COVID-19 Crisis. (2020). Available online at: https://zeenews.india.com/india/india-approves-malaysia-s-requestfor-supplying-hydroxychloroquine-drug-to-deal-with-covid-19-crisis2279664.html (accessed September 25, 2020).

184. Channnel News Asia. Malaysia Still Using Hydroxychloroquine to Treat COVID-19 Patients; Health Ministry Monitoring Side Effects. (2020). Available online at: https://www.channelnewsasia.com/news/asia/covid-19malaysia-hydroxychloroquine-still-using-treatment-12771770 (accessed September 26, 2020). 
185. Batumalai K. Malaysia Finds Hydroxychloroquine Can Slow Covid-19 Progress. (2020). Available online at: https://codeblue.galencentre.org/2020/ 06/09/malaysia-finds-hydroxychloroquine-can-slow-covid-19-progress/ (accessed September 25, 2020).

186. Deccan Herald. Pakistan Bans Export of Hydroxychloroquine, Medicine Against COVID-19. (2020). Available online at: https://www.deccanherald. $\mathrm{com} /$ international/pakistan-bans- export-of-hydroxychloroquinemedicine-against-covid-19-824075.html (accessed September 25, 2020).

187. Sajid I. COVID-19: Pakistan to Send Chloroquine to Allies - Cabinet Approves Export of Anti-Malaria Drug to Turkey, Qatar, US, Saudi and UK to Treat COVID-19 Patients. (2020). Available online at: https://www.aa.com.tr/ en/asia-pacific/covid-19-pakistan-to-send-chloroquine-to-allies/1813201 (accessed September 26, 2020).

188. NIH Clinical Trials.gov. The Vietnam Chloroquine Treatment on COVID19 (VICO). (2020). Available online at: https://clinicaltrials.gov/ct2/show/ NCT04328493 (accessed September 25, 2020).

189. Ying TP. Dr Noor Hisham: Malaysia Drops Use of Hydroxychloroquine for Covid-19. (2020). Available online at: https://www.nst.com.my/ news/nation/2020/06/602538/dr-noor-hisham-malaysia-drops-usehydroxychloroquine-covid-19 (accessed September 26, 2020).

190. RECOVERY Collaborative Group. Lopinavir-ritonavir in patients admitted to hospital with COVID-19 (RECOVERY): a randomised, controlled, open-label, platform trial. Lancet. (2020) 396:1345-52. doi: 10.1016/S0140-6736(20)32013-4

191. Mehra MR, Ruschitzka F, Patel AN. Retraction-Hydroxychloroquine or chloroquine with or without a macrolide for treatment of COVID-19: a multinational registry analysis. Lancet. (2020). doi: 10.1016/S0140-6736(20)31180-6. [Epub ahead of print].

192. Bae S, Kim MC, Kim JY, Cha HH, Lim JS, Jung J, et al. Notice of retraction: effectiveness of surgical and cotton masks in blocking SARS-CoV-2. Ann Int Med. (2020). doi: 10.7326/L20-0745. [Epub ahead of print].

193. Nga L, Phuong L, Anh P. Hanoi Man OD's on Rumored Malaria Drug Cure for Covid-19. (2020). Available online at: https://e.vnexpress.net/news/news/ hanoi-man-od-s-on-rumored-malaria-drug-cure-for-covid-19-4073488. html

194. Politi D. Nigeria Reports Chloroquine Poisonings as Trump Keeps Pushing Drug Against Coronavirus. (2020). Available online at: https://slate. com/news-and-politics/2020/03/nigeria-chloroquine-poisonings-trumppushing-drug-coronavirus.html

195. Das S, Bhowmick S, Tiwari S, Sen S. An updated systematic review of the therapeutic role of hydroxychloroquine in coronavirus disease-19 (COVID19). Clin Drug Investig. (2020) 40:591-601. doi: 10.1007/s40261-02000927-1

196. Godman B. Combating COVID-19: lessons learnt particularly among developing countries and the implications. Bang J Med Sci. (2020) 19:S103-8. doi: 10.3329/bjms.v19i0.48413

197. Jakovljevic MB, Milovanovic O. Growing burden of non-communicable diseases in the emerging health markets: the case of BRICS. Front Public Health. (2015) 3:65. doi: 10.3389/fpubh.2015.00065

198. Mukhtar S. Mental health and psychosocial aspects of coronavirus outbreak in Pakistan: psychological intervention for public mental health crisis. Asian J Psychiatry. (2020) 51:102069. doi: 10.1016/j.ajp.2020.102069

199. Salum GA, Rehmenklau JF, Csordas MC, Pereira FP, Castan JU, Ferreira AB, et al. Supporting people with severe mental health conditions during the COVID-19 pandemic: considerations for low- and middle-income countries using telehealth case management. Rev Bras Psiquiatria. (2020) 42:451-2. doi: 10.1590/1516-4446-2020-1078

200. Chandir S, Siddiqi DA, Setayesh H, Khan AJ. Impact of COVID-19 lockdown on routine immunisation in Karachi, Pakistan. Lancet Global Health. (2020) 8:e1118-20. doi: 10.1016/S2214-109X(20)30290-4

201. Banerjee SK. Dealing With Immunisation During the COVID-19 Pandemic: India's Experience. (2020). Available online at: https:// www.europeanpharmaceuticalreview.com/article/119520/dealing-withimmunisation-during-the-covid-19-pandemic-indias-experience/ (accessed September 25, 2020).

202. FIP. FIP Health Advisory Coronavirus SARS-CoV-2/COVID-19 Pandemic: Information and Interim Guidelines for Pharmacists and the Pharmacy Workforce. (2020). Available online at: https://www.fip.org/files/content/
priority-areas/coronavirus/Coronavirus-guidance- update-ENGLISH.pdf (accessed September 26, 2020).

203. WHO. Community Pharmacists are Key Players in COVID-19 Response and Must Stay Up-To-Date on Guidance. (2020). Available online at: https://www. euro.who.int/en/health-topics/health-emergencies/coronavirus-covid-19/ news/news/2020/5/community-pharmacists-are-key-players-in-covid-19response-and-must-stay-up-to-date-on-guidance (accessed September 25, 2020).

204. Ung COL. Community pharmacist in public health emergencies: Quick to action against the coronavirus 2019 -nCoV outbreak. Res Soc Admin Pharm. (2020) 16:583-6. doi: 10.1016/j.sapharm.2020.02.003

205. San-Juan-Rodriguez A, Newman TV, Hernandez I, Swart ECS, Klein-Fedyshin M, Shrank WH, et al. Impact of community pharmacist-provided preventive services on clinical, utilization, and economic outcomes: an umbrella review. Prev Med. (2018) 115:145-55. doi: 10.1016/j.ypmed.2018.08.029

206. Weston M. Coronavirus Reaches Sudan, One of the Countries Least Equipped to Cope With It. (2020). Available online at: https://mg.co.za/africa/2020-0324-coronavirus-reaches-sudan- one- of-the-countries-least-equipped-tocope-with-it/ (accessed September 25, 2020).

207. Topp S. Malaysia's Youngest Hospital CEO On Fighting Coronavirus On The Front Lines. (2020). Available online at: https://generationt.asia/leaders/ malaysias-youngest-hospital-ceo-on-fighting-coronavirus-on-the-frontlines

208. Buasi S, Adebayo B. Nigeria Records Chloroquine Poisoning After Trump Endorses It for Coronavirus Treatment. (2020) Available online at: https://edition.cnn.com/2020/03/23/africa/chloroquine-trump-nigeriaintl/index.html (accessed September 26, 2020).

209. Luo L, Jiang J, Wang C, Fitzgerald M, Hu W, Zhou Y, et al. Analysis on herbal medicines utilized for treatment of COVID-19. Acta Pharm Sin B. (2020) 10:1192-20. doi: 10.1016/j.apsb.2020.05.007

210. Nkeck JR, Tsafack EE, Ndoadoumgue AL, Endomba FT. An alert on the incautious use of herbal medicines by sub-Saharan African populations to fight against the COVID-19. PAMJ. (2020) 35:26. 10.11604/pamj.supp.2020.35.2.23161. doi: 10.11604/pamj.supp.2020.35.2.23161

211. Godman B, Basu D, Pillay Y, Mwita JC, Rwegerera GM, Anand Paramadhas $\mathrm{BD}$, et al. Review of ongoing activities and challenges to improve the care of patients with type 2 diabetes across Africa and the implications for the future. Front Pharmacol. (2020) 11:108. doi: 10.3389/fphar.2020.00108

212. Godman B, McCabe H, Leong TD. Fixed dose drug combinations - are they pharmacoeconomically sound? Findings and implications especially for lower- and middle-income countries. Exp Rev Pharm Outcomes Res. (2020) 20:1-26. doi: 10.1080/14737167.2020.1734456

213. Godman B, Grobler C, Van-De-Lisle M, Wale J, Barbosa WB, Massele A, et al. Pharmacotherapeutic interventions for bipolar disorder type II: addressing multiple symptoms and approaches with a particular emphasis on strategies in lower and middle-income countries. Exp Opin Pharmacother. (2019) 20:2237-55. doi: 10.1080/14656566.2019.1684473

214. Godman B, Basu D, Pillay Y, Almeida P, Mwita JC, Rwegerera GM, et al. Ongoing and planned activities to improve the management of patients with Type 1 diabetes across Africa; implications for the future. Hosp Pract. (2020) 48:51-67. doi: 10.1080/21548331.2020.1745509

215. Godman B, Bucsics A, Vella Bonanno P, Oortwijn W, Rothe CC, Ferrario A, et al. Barriers for access to new medicines: searching for the balance between rising costs and limited budgets. Front Public Health. (2018) 6:328. doi: 10.3389/fpubh.2018.00328

216. Gad M, Salem A, Oortwijn W, Hill R, Godman B. Mapping of current obstacles for rationalizing use of medicines (CORUM) in Europe: current situation and potential solutions. Front Pharmacol. (2020) 11:144. doi: 10.3389/fphar.2020.00144

217. Moorkens E, Vulto AG, Huys I, Dylst P, Godman B, Keuerleber S, et al. Policies for biosimilar uptake in Europe: an overview. PLoS ONE. (2017) 12:e190147. doi: 10.1371/journal.pone.0190147

218. Godman B, Hill A, Simoens S, Kurdi A, Gulbinovič J, Martin AP et al. Pricing of oral generic cancer medicines in 25 European countries; findings and implications. Generics Biosimilars Initiat J. (2019) 8:49-70. doi: $10.5639 /$ gabij.2019.0802.007 
219. Miljković N, Godman B, van Overbeeke E, Kovačević M, Tsiakitzis K, Apatsidou A, et al. Risks in antibiotic substitution following medicine shortage: a health-care failure mode and effect analysis of six European hospitals. Front Med. (2020) 7:157. doi: 10.3389/fmed.2020.00157

220. Council for International Organizations Of Medical Sciences. Medicines Assessment During Public Health Emergencies Needs Good Science, Best Practices and Proper Communication. (2020). Available online at: https:// cioms.ch/wp-content/uploads/2020/06/CIOMS_WGXII_Statement.pdf (accessed September 24, 2020).

221. Davis R. Viral Outbreak: Fake News Spreads in SA in Tandem With Covid-19. (2020). Available online at: https://www.dailymaverick.co.za/article/202003-31-viral-outbreak-fake-news-spreads-in-sa-in-tandem-with-covid-19/ (accessed September 25, 2020).

222. Dzirutwe M. Zimbabwe President Threatens 20 Years Jail Over Fake Covid-19 Statement. (2020). Available online at: https://www.sowetanlive.co.za/news/ africa/2020-04-14-zimbabwe-president-threatens-20-years-jail-over-fakecovid-19-statement/ (accessed September 24, 2020).

223. Alrasheedy AA, Alsalloum MA, Almuqbil FA, Almuzaini MA, Aba Alkhayl BS, Albishri AS, et al. The impact of law enforcement on dispensing antibiotics without prescription: a multi-methods study from Saudi Arabia. Exp Rev Anti Infect Ther. (2020) 18:87-97. doi: 10.1080/14787210.2020.1705156

224. Habersaat KB, Betsch C, Danchin M, Sunstein CR, Böhm R, Falk A, et al. Ten considerations for effectively managing the COVID-19 transition. Nat Hum Behav. (2020) 4:677-87. doi: 10.1038/s41562-020-0906-x

225. Ongole JJ, Rossouw TM, Fourie PB, Stoltz AC, Hugo J, Marcus TS. Sustaining Essential Healthcare in Africa During the COVID19 Pandemic. (2020). Available online at: https://www.theunion.org/news-centre/news/ body/IJTLD-June-0214_Ongole.pdf (accessed September 25, 2020).

226. Hedima EW, Adeyemi MS, Ikunaiye NY. Community pharmacists: on the frontline of health service against COVID-19 in LMICs. Res Soc Admin Pharm. (2020). doi: 10.1016/j.sapharm.2020.04.013. [Epub ahead of print].

227. Hoxha I, Malaj A, Kraja B, Bino S, Oluka M, Markovic-Pekovic V, et al. Are pharmacists' good knowledge and awareness on antibiotics taken for granted? The situation in Albania and future implications across countries. J Global Antimicrob Resist. (2018) 13:240-5. doi: 10.1016/j.jgar.2018. 01.019

228. Kamati M, Godman B, Kibuule D. Prevalence of self-medication for acute respiratory infections in young children in Namibia: findings and implications. J Res Pharm Pract. (2019) 8:220-4. doi: 10.4103/jrpp.JRPP_19_121

229. Mukokinya M, Opanga S, Oluka M, Godman B. Dispensing of antimicrobials in Kenya: a cross-sectional pilot study and its implications. J Res Pharm Pract. (2018) 7:77-82. doi: 10.4103/jrpp.JRPP_17_88

230. Jacobs TG, Robertson J, van den Ham HA, Iwamoto K, Bak Pedersen H, Mantel-Teeuwisse AK. Assessing the impact of law enforcement to reduce over-the-counter (OTC) sales of antibiotics in low- and middle-income countries; a systematic literature review. BMC Health Serv Res. (2019) 19:536. doi: 10.1186/s12913-019-4359-8

231. Abena PM, Decloedt EH, Bottieau E, Suleman F, Adejumo P, Sam-Agudu $\mathrm{NA}$, et al. Chloroquine and hydroxychloroquine for the prevention or treatment of COVID-19 in Africa: caution for inappropriate off-label use in healthcare settings. Am J Trop Med Hyg. (2020) 102:1184-8. doi: 10.4269/ajtmh.20-0290
232. Busari S, Adebayo B. Nigeria Records Chloroquine Poisoning After Trump Endorses It for Coronavirus Treatment. (2020). Available online at: https://www.cnnphilippines.com/world/2020/3/23/nigeria-chloroquinepoisoning-trump-coronavirus.html (accessed September 25, 2020).

233. World Health Organisation. The Potential Impact of Health Service Disruptions on the Burden of Malaria: A Modelling Analysis for Countries in Sub-Saharan Africa. (2020). Available online at: https://apps.who.int/ iris/bitstream/handle/10665/331845/9789240004641-eng.pdf?sequence $=1 \&$ isAllowed $=\mathrm{y}$ (accessed September 24, 2020).

234. Krubiner C, Keller JM, Kaufman J. Balancing the COVID-19 Response with Wider Health Needs: Key Decision-Making Considerations for Low- and Middle-Income Countries. (2020). Available online at: https://www.cgdev. $\mathrm{org} /$ sites/default/files/balancing-covid-19-response-wider-health-needskey-decision-making-considerations-low.pdf (accessed September 24, 2020).

235. Cash R, Patel V. The art of medicine - Has COVID-19 subverted global health? Lancet. (2020) 395:1687-8. doi: 10.1016/S0140-6736(20)31089-8

236. Abbas K, Procter SR, van Zandvoort K, Clark A, Funk S, Mengistu T, et al. Routine childhood immunisation during the COVID-19 pandemic in Africa: a benefit-risk analysis of health benefits versus excess risk of SARS-CoV-2 infection. Lancet Global Health. (2020) 8:e1264-72. doi: 10.1016/S2214-109X(20)30308-9

237. Stoll J, Sadler JZ, Trachsel M. The ethical use of telepsychiatry in the Covid-19 pandemic. Front Psychiatry. (2020) 11:665. doi: 10.3389/fpsyt.2020.00665

Conflict of Interest: AR, MK, and MonH were employed by Grameen Euglena, Al-Manar Hospital Ltd. \& Modern Hospital Cumilla Ltd., and Square Toiletries Limited, Dhaka, Bangladesh, respectively.

The remaining authors declare that the research was conducted in the absence of any commercial or financial relationships that could be construed as a potential conflict of interest.

Received: 17 August 2020; Accepted: 15 October 2020; Published: 14 December 2020

Specialty section: This article was submitted to Health Economics, a section of the journal Frontiers in Public Health

Citation: Godman B, Haque M, Islam S, Iqbal S, Urmi UL, Kamal ZM, Shuvo SA, Rahman A, Kamal M, Haque M, Jahan I, Islam MZ, Hossain MM, MunzurE-Murshid, Kumar S, Charan J, Bhatt R, Dutta S, Abhayanand JP, Sharma Y, Saleem Z, Phuong TNT, Kwon H-Y, Kurdi A, Wale J and Sefah I (2020) Rapid Assessment of Price Instability and Paucity of Medicines and Protection for COVID-19 Across Asia: Findings and Public Health Implications for the Future. Front. Public Health 8:585832. doi: 10.3389/fpubh.2020.585832

Copyright (c) 2020 Godman, Haque, Islam, Iqbal, Urmi, Kamal, Shuvo, Rahman, Kamal, Haque, Jahan, Islam, Hossain, Munzur-E-Murshid, Kumar, Charan, Bhatt, Dutta, Abhayanand, Sharma, Saleem, Phuong, Kwon, Kurdi, Wale and Sefah. This is an open-access article distributed under the terms of the Creative Commons Attribution License (CC BY). The use, distribution or reproduction in other forums is permitted, provided the original author(s) and the copyright owner(s) are credited and that the original publication in this journal is cited, in accordance with accepted academic practice. No use, distribution or reproduction is permitted which does not comply with these terms. 